\title{
Application of Extrusion-Based Hydrogel Bioprinting for Cartilage Tissue Engineering
}

\author{
Fu You ${ }^{1}$, B. Frank Eames ${ }^{1,2}$ and Xiongbiao Chen ${ }^{1,3, *}$ \\ 1 Division of Biomedical Engineering, College of Engineering, University of Saskatchewan, 57 Campus Drive, \\ Saskatoon, SK S7N 5A9, Canada; fuy618@campus.usask.ca (F.Y.); b.frank@usask.ca (B.F.E.) \\ 2 Department of Anatomy and Cell Biology, College of Medicine, University of Saskatchewan, 107 Wiggins \\ Road, Saskatoon, SK S7N 5E5, Canada \\ 3 Department of Mechanical Engineering, College of Engineering, University of Saskatchewan, 57 Campus \\ Drive, Saskatoon, SK S7N 5A9, Canada \\ * Correspondence: xbc719@mail.usask.ca; Tel.: +1-(306)-966-1267
}

Received: 7 June 2017; Accepted: 16 July 2017; Published: 23 July 2017

\begin{abstract}
Extrusion-based bioprinting (EBB) is a rapidly developing technique that has made substantial progress in the fabrication of constructs for cartilage tissue engineering (CTE) over the past decade. With this technique, cell-laden hydrogels or bio-inks have been extruded onto printing stages, layer-by-layer, to form three-dimensional (3D) constructs with varying sizes, shapes, and resolutions. This paper reviews the cell sources and hydrogels that can be used for bio-ink formulations in CTE application. Additionally, this paper discusses the important properties of bio-inks to be applied in the EBB technique, including biocompatibility, printability, as well as mechanical properties. The printability of a bio-ink is associated with the formation of first layer, ink rheological properties, and crosslinking mechanisms. Further, this paper discusses two bioprinting approaches to build up cartilage constructs, i.e., self-supporting hydrogel bioprinting and hybrid bioprinting, along with their applications in fabricating chondral, osteochondral, and zonally organized cartilage regenerative constructs. Lastly, current limitations and future opportunities of EBB in printing cartilage regenerative constructs are reviewed.
\end{abstract}

Keywords: cartilage tissue engineering; extrusion-based bioprinting; hydrogels; bio-inks; self-supporting hydrogel bioprinting; hybrid bioprinting

\section{Bioprinting Is a Promising Technique to Process Hydrogel for Fabricating Cartilage Constructs}

Bioprinting of personalized complex tissue grafts is promising for overcoming the current challenges of cartilage tissue engineering (CTE). Cartilage is a highly hydrated and specialized tissue to provide a low-friction, wear-resistant, and load-bearing surface in diarthrodial joints for efficient joint movement [1]. Unfortunately, the structure and function of the cartilage are frequently disrupted or lost with trauma or aging; moreover, there is no sufficient heal response for regeneration as cartilage shows little self-repair tendency. These defects or injuries last for years and eventually lead to arthritis [2]. To address this problem, tissue engineering (TE) approaches aiming to engineer constructs to regenerate cartilage defects are under active investigation. Ideally, the tissue-engineered constructs for CTE should fill cartilage defects, resemble extracellular matrix (ECM), hold cells in place, and retain a space for the growing tissue [3,4]. To this end, hydrogel has been illustrated promising due to the fact that it closely mimics native ECM and thus providing a 3D culture microenvironment favorable for encapsulated cells to retain the rounded morphology and chondrogenic phenotype [5-7]. Furthermore, hydrogels allow for achieving high cell seeding density and homogenous cell distribution throughout scaffold [6,8-14], and transmitting external stimuli to embedded cells so as to direct growth and formation of the regenerating cartilage $[15,16]$. Several disadvantages of hydrogels, however, have also 
been identified, such as weak mechanical strength and stability. It is also hard to handle and process hydrogels into cartilage regenerative constructs with desired internal structure and external shape. To overcome these problems, the bioprinting technique has been rapidly developing and gaining interest for fabrication of customized cartilage constructs.

Although some reviews on bioprinting of tissues and organs are available, investigation into the extrusion-based bioprinting (EBB) of cartilage constructs from bio-inks has not been well-documented. This article presents a brief review of the application of EBB for fabricating cartilage constructs from bio-inks, covering its working principles, applicable cell sources and materials, printability, printed cartilage constructs, as well as future perspectives of bioprinting cartilage.

\section{Extrusion-Based Bioprinting and Bio-Inks for Cartilage Tissue Engineering}

\subsection{Extrusion-Based Bioprinting}

Rapid prototyping (RP), also known as solid freeform fabrication, refer to a series of techniques that manufacture objects through sequential delivery of energy and/or material in a layer-by-layer manner per computer aided design (CAD) data. The external shape and internal architecture of the scaffold can be defined by either 3D computer models or clinical imaging data (e.g., the defect area of the patient can be scanned by magnetic resonance imaging or computed tomography) $[17,18]$. Once the external/internal geometric information is determined, the RP system is programed to fabricate the scaffold as designed.

Among various RP techniques, EBB stands out for its unique advantages. It allows for production of $3 \mathrm{D}$ tissue constructs from bio-inks by a layer-by-layer deposition process in a designed way [19]. EBB also allows for higher cell seeding density, higher printing speed to facilitate scalability, and relatively less process-induced cell damage compared to other techniques [20]. EBB can print continuous cylindrical filaments from almost all types of bio-inks to high cell density aggregates of a wide range of viscosities. Once the bio-ink is printed, it can be crosslinked by ionic, photo, and/or thermal crosslinking mechanisms (Figure 1). Given the complexity of biological tissue, multiple bio-inks are often used to fabricate a tissue construct, which is also achievable by using EBB with multiple printing heads.

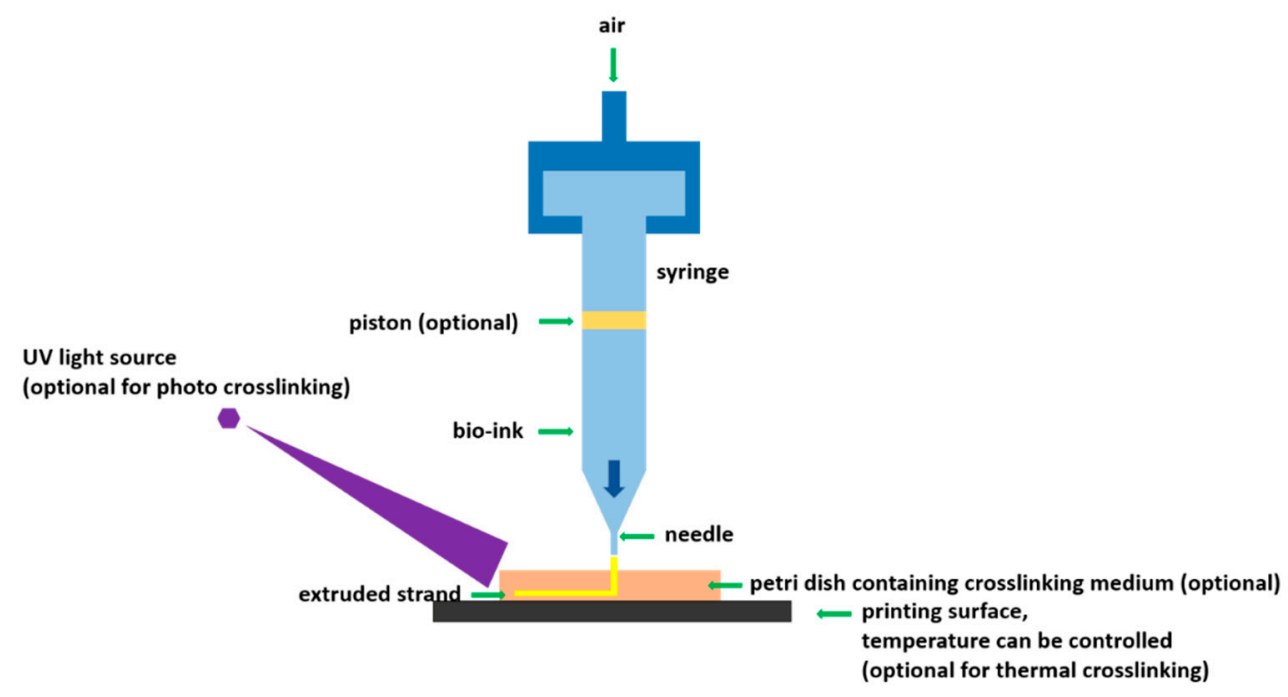

Figure 1. Schematic of extrusion-based bioprinting using various crosslinking mechanisms.

\subsection{Bio-Inks}

Hydrogel precursors and living cells are two important components of bio-ink formulations. Cell sources and hydrogel types employed for encapsulating chondrogenic cells are reviewed below. 


\subsubsection{Applicable Cell Sources}

The choice of cells is a central problem to any modality of TE. For cartilage bioprinting, several factors need to be taken into consideration when choosing suitable cell sources: (i) cells must be robust enough to survive any shear stress and pressure during the printing process; (ii) cells must proliferate well; (iii) cells must possess biosynthesis levels (e.g., of proteoglycans, Collagen type II) comparable with native chondrocytes so they can maintain their biological functions [21]. So far, the use of chondrocytes over stem cells for cartilage bioprinting is predominant (Table 1).

Consistent with the distinct zonal structure of native articular cartilage [22], chondrocytes from different zones show different characteristics of biosynthesis levels. Superficial zone has a dense network of collagen fibers that are parallel to the articular surface, while collagen fibers are randomly arranged in the middle region and perpendicular to the subchondral bone in the deep zone [23]. The content of the other important component in cartilage, proteoglycan, is lowest in the superficial zone and increases through the middle and deep zones [24]. Limited number of chondrocytes in articular cartilage makes it necessary to expand chondrocytes before use. The monolayer expansion process usually leads to chondrocyte dedifferentiation with decreased GAG synthesis and Collagen type II expression $[25,26]$. Most studies typically use chondrocyte mixtures from full-thickness cartilage [27-29] to obtain higher cell populations. Recently, more attention has been focused on employing zonal chondrocytes to achieve different purposes. For example, deep zone chondrocytes are utilized to engineer a functional osteochondral interface by coculturing with calcium phosphate [30]. Chondrocytes isolated from the superficial layer exhibit increased proteoglycan 4 expression, and thus superficial chondrocytes are promising to be used as the cell source for engineering articular surface [1]. Articular chondrocytes provide researchers with a unique opportunity to replicate the native zonal structure by embedding and culturing zonal chondrocytes in different layers of gels, although it is still elusive if this is a promising approach or an overcomplicated strategy [31]. Donor site morbidity during harvesting of joint cartilage further limits the use of articular chondrocytes [32]. Therefore, nasoseptal chondrocytes, as another autologous chondrocyte source, is also explored for bioprinting cartilage constructs $[33,34]$. Another promising cell type is the multipotent mesenchymal stem cell (MSC), which can be derived from multiple tissues, such as bone marrow, adipose tissues, synovium, periosteum, and muscle. These stem cells can be differentiated to undergo chondrogenesis with the supplement of specific growth factors [35,36], such as transforming growth factor beta family [37] and therefore they have been explored to be used in CTE [38-44].

Table 1. Cell sources that have been used in cartilage tissue engineering (CTE) or cartilage bioprinting.

\begin{tabular}{llll}
\hline Cell Source & \multicolumn{1}{c}{ Features } & \multicolumn{1}{c}{$\begin{array}{c}\text { References for } \\
\text { Application in CTE }\end{array}$} & $\begin{array}{c}\text { Chondrocytes } \\
\text { Application in } \\
\text { Bioprinting for CTE }\end{array}$ \\
\hline Artcicular & $\begin{array}{l}\text { ease of induction, make it easy to replicate native } \\
\text { zonal cartilage by using zonal chondrocytes. } \\
\text { Invasive harvesting procedure, donor site } \\
\text { morbidity, low cell yields, low bioactivity, tend to } \\
\text { dedifferentiate during expansion. }\end{array}$ & {$[45-51]$} & \\
\hline Auricular & $\begin{array}{l}\text { elastic cartilage, Faster cell proliferation rates than } \\
\text { articular chondrocytes, produce more } \\
\text { biochemically and histologically similar cartilage } \\
\text { than articular chondrocytes when implanted } \\
\text { in vivo. }\end{array}$ & [52-54] \\
\hline Nasoseptal & $\begin{array}{l}\text { hyaline cartilage, proliferate faster and less } \\
\text { tendency of dedifferentiation than articular } \\
\text { chondrocytes when culturing monolayer, capable } \\
\text { of producing a cartilage ECM with a high GAG } \\
\text { accumulation and Collagen type II/I. }\end{array}$ & [33,34,55,56] \\
\hline
\end{tabular}


Table 1. Cont.

\begin{tabular}{|c|c|c|c|}
\hline Cell Source & Features & $\begin{array}{c}\text { References for } \\
\text { Application in CTE }\end{array}$ & $\begin{array}{c}\text { References for } \\
\text { Application in } \\
\text { Bioprinting for CTE }\end{array}$ \\
\hline \multicolumn{4}{|c|}{ MSC } \\
\hline $\begin{array}{l}\text { Bone } \\
\text { marrow }\end{array}$ & $\begin{array}{l}\text { high differentiation potentials and less morbidity } \\
\text { during harvesting, chondrogenesis under } \\
\text { appropriate culture conditions, involving the } \\
\text { supplementation of growth factors such as TGF- } \beta \text {, } \\
\text { FGF-2. }\end{array}$ & {$[38,57-59]$} & [58] \\
\hline Adipose & $\begin{array}{l}\text { differentiating into chondrocytes in the presence of } \\
\text { TGF- } \beta \text {, ascorbate, and dexamethasone, lower } \\
\text { chondrogenesis. potential than stem cells from } \\
\text { other sources, lower deposition of cartilage ECM } \\
\text { than other cell types. }\end{array}$ & {$[39,60,61]$} & - \\
\hline Muscle & $\begin{array}{l}\text { differentiation into various lineages, induction to } \\
\text { chondrocytes with the addition of BMP- } 2 \text {, } \\
\text { improved healing of cartilage defect with } \\
\text { an efficacy equivalent to chondrocytes. }\end{array}$ & {$[40,41,62-64]$} & - \\
\hline Synovium & $\begin{array}{l}\text { greater chondrogenic potential than stem cells from } \\
\text { other sources, comparable biosynthesis level with } \\
\text { articular chondrocytes in terms of Collagen type II, } \\
\text { aggrecan. }\end{array}$ & {$[62,65-67]$} & - \\
\hline Periosteum & $\begin{array}{l}\text { good accessibility, proliferate faster that stem cells } \\
\text { from other sources, and capability to differentiate } \\
\text { into multiple mesenchymal lineages, including } \\
\text { bone and cartilage. }\end{array}$ & {$[42,68]$} & - \\
\hline
\end{tabular}

\subsubsection{Applicable Hydrogel-Forming Polymers for Formulating Bio-Inks}

Hydrogel cross-linking mechanisms are generally categorized into "physical" crosslinking and "chemical" crosslinking. Physical (thermal [69,70] ionic [71] and photo [72]) crosslinking include reversible entangled chains, hydrogen bonding, etc. while chemical (enzyme [73] and pH [74]) crosslinking are permanent junctions formed by irreversible, covalent bonds. Hydrogel can be classified into two groups based on their sources: natural hydrogels (e.g., agarose, alginate, cellulose, gelatin, gellan gum, hyaluronic acid, collagen, fibrin) and synthetic hydrogels (e.g., Pluronic ${ }^{\circledR}$ F127, PEG, and PVA). Hydrogels that are biocompatible for encapsulating stem cells or chondrogenic cells for CTE are summarized and reviewed (Table 2). There are pros and cons to each type of these hydrogels and researchers attempted to modify these polymers to improve their properties like bioactivity, mechanical properties, and printability. 
Table 2. Toolkit of bio-ink formulation.

\begin{tabular}{|c|c|c|c|c|c|c|}
\hline Materials & Crosslinking & Advantages & Disadvantages & Encapsulated Cells & $\begin{array}{c}\text { References in } \\
\text { Other Techniques }\end{array}$ & $\begin{array}{c}\text { References in } \\
\text { Bioprinting }\end{array}$ \\
\hline Agarose & $\begin{array}{l}\text { thermal crosslinking at } 26-30^{\circ} \mathrm{C} \text {, } \\
\text { extruded agarose solidifies by } \\
\text { bioprinting onto a surface of which } \\
\text { temperature is lower than the } \\
\text { thermal crosslinking temperature }\end{array}$ & $\begin{array}{l}\text { simple and non-toxic } \\
\text { crosslinking process, good } \\
\text { mechanical properties, and } \\
\text { stability of printed construct }\end{array}$ & $\begin{array}{l}\text { not degradable, poor cell } \\
\text { adhesion, impaired cell } \\
\text { viability due to high } \\
\text { temperature to dissolve } \\
\text { agarose }\end{array}$ & $\begin{array}{l}\text { bone marrow stem } \\
\text { cells(BMSC), adipose } \\
\text { stem cells (ASC) }\end{array}$ & [75-77] & [78] \\
\hline Alginate & $\begin{array}{l}\text { ionic crosslinking with } \\
\text { divalent cations }\end{array}$ & $\begin{array}{l}\text { rapid gelation, high } \\
\text { printability, biocompatible, } \\
\text { good stability, and } \\
\text { integrality of printed } \\
\text { construct }\end{array}$ & $\begin{array}{l}\text { poor cell adhesion, } \\
\text { this disadvantage can be } \\
\text { overcome by modifying } \\
\text { alginate with arginyl glycyl } \\
\text { aspartic acid, Collagen type } \\
\text { I or oxygenation }\end{array}$ & $\begin{array}{l}\text { BMSC, ASC, } \\
\text { chondrocytes }\end{array}$ & [79-81] & [82] \\
\hline Methylcellulose & $\begin{array}{l}\text { thermal crosslinking below } 37^{\circ} \mathrm{C} \text {, } \\
\text { silanized hydroxypropyl } \\
\text { methylcellulose can be synthesized } \\
\text { to be crosslinked by changing } \mathrm{pH}\end{array}$ & $\begin{array}{l}\text { good printability, } \\
\text { biocompatibility }\end{array}$ & $\begin{array}{l}\text { partially degrade when } \\
\text { culturing in cell culture } \\
\text { media and therefore not } \\
\text { suitable for long-term } \\
\text { culturing }\end{array}$ & chondrocytes & [83-85] & [35] \\
\hline Chitosan & ionic or covalent crosslinking & $\begin{array}{l}\text { biocompatibility, } \\
\text { antibacterial }\end{array}$ & $\begin{array}{l}\text { slow gelation rate and poor } \\
\text { mechanical properties } \\
\text { without modification }\end{array}$ & BMSC & [86-88] & [89] \\
\hline Gellan gum & $\begin{array}{l}\text { thermal crosslinking or ionic } \\
\text { crosslinking with divalent cation }\end{array}$ & $\begin{array}{l}\text { biocompatible, high } \\
\text { printability }\end{array}$ & poor cellular adhesion & $\begin{array}{l}\text { ASC, nasal } \\
\text { chondrocytes }\end{array}$ & [90-92] & {$[93,94]$} \\
\hline Hyaluronic acid & $\begin{array}{l}\text { ionic or covalent crosslinking, } \\
\text { functionalized with methacrylate to } \\
\text { be photocrosslinkable }\end{array}$ & $\begin{array}{l}\text { promote cell proliferation, } \\
\text { fast gelation, high } \\
\text { printability with suitable } \\
\text { modification, have } \\
\text { lubricating properties }\end{array}$ & $\begin{array}{l}\text { fast degradation, poor } \\
\text { mechanical properties and } \\
\text { stability without } \\
\text { modification }\end{array}$ & $\begin{array}{l}\text { BMSC, chondrocytes, } \\
\text { fibroblasts }\end{array}$ & [95-98] & [99] \\
\hline Gelatin & $\begin{array}{l}\text { thermal crosslinking, } \\
\text { photocrosslinkable polymers can be } \\
\text { obtained by functionalization } \\
\text { withmethacrylamide side groups to } \\
\text { make it stable at } 37^{\circ} \mathrm{C}\end{array}$ & $\begin{array}{l}\text { biocompatibility, high cell } \\
\text { adhesion support cell } \\
\text { viability and proliferation }\end{array}$ & $\begin{array}{l}\text { poor mechanical properties } \\
\text { and stability, low } \\
\text { printability }\end{array}$ & $\begin{array}{l}\text { BMSC, fibroblasts, } \\
\text { chondrocytes }\end{array}$ & [100-102] & {$[69,72,103]$} \\
\hline
\end{tabular}


Table 2. Cont.

\begin{tabular}{|c|c|c|c|c|c|c|}
\hline Materials & Crosslinking & Advantages & Disadvantages & Encapsulated Cells & $\begin{array}{c}\text { References in } \\
\text { Other Techniques }\end{array}$ & $\begin{array}{c}\text { References in } \\
\text { Bioprinting }\end{array}$ \\
\hline Collagen & $\begin{array}{l}\mathrm{pH} \text { crosslinking }(7-7.4) \text { at } 37^{\circ} \mathrm{C} \text { or } \\
\text { thermal crosslinking }\end{array}$ & $\begin{array}{l}\text { biocompatibility, high cell } \\
\text { adhesion, promote cell } \\
\text { proliferation and serve as } \\
\text { a signal transducer, high } \\
\text { printability }\end{array}$ & $\begin{array}{l}\text { low gelation rate, poor } \\
\text { mechanical properties and } \\
\text { stability }\end{array}$ & $\begin{array}{l}\text { BMSC, fibroblasts, } \\
\text { chondrocytes }\end{array}$ & [104-106] & {$[107,108]$} \\
\hline Fibrin & $\begin{array}{l}\text { enzymatic crosslinking, gels when } \\
\text { combining fibrinogen, } \mathrm{Ca}^{2+} \text { and } \\
\text { thrombin at room temperature }\end{array}$ & $\begin{array}{l}\text { biocompatibility, high cell } \\
\text { adhesion, rapid gelation }\end{array}$ & $\begin{array}{l}\text { limited printability and } \\
\text { poor mechanical properties }\end{array}$ & BMSC, chondrocytes & [109] & [110-112] \\
\hline Matrigel & $\begin{array}{l}\text { irreversible thermal crosslinking at } \\
24-37^{\circ} \mathrm{C}\end{array}$ & $\begin{array}{l}\text { biocompatibility, support } \\
\text { cell viability and } \\
\text { differentiation, high } \\
\text { printability }\end{array}$ & $\begin{array}{l}\text { slow gelation and poor } \\
\text { stability }\end{array}$ & BMSC, chondrocytes & {$[113,114]$} & [115] \\
\hline Pluronic $^{\circledR}$ F127 & thermal crosslinking & $\begin{array}{l}\text { biocompatibility, high } \\
\text { printability, support cell } \\
\text { viability }\end{array}$ & $\begin{array}{l}\text { weak stability and } \\
\text { mechanical properties, fast } \\
\text { degradation, slow gelation }\end{array}$ & BMSC, fibroblasts & {$[74,116,117]$} & [118] \\
\hline $\begin{array}{l}\text { Poly(ethylene } \\
\text { glycol) }\end{array}$ & $\begin{array}{l}\text { radiation crosslinking or free } \\
\text { radical polymerization }\end{array}$ & $\begin{array}{l}\text { biocompatibility, support } \\
\text { cell viability, can be easily } \\
\text { modified with various } \\
\text { functional groups }\end{array}$ & $\begin{array}{l}\text { poor cellular adhesion, low } \\
\text { cell proliferation rate }\end{array}$ & BMSC, chondrocytes & {$[119,120]$} & [121] \\
\hline
\end{tabular}




\section{Important Properties of Bio-Inks}

\subsection{Biocompatibility}

Biocompatibility must be considered before the application of any material for TE and regenerative medicine. Biocompatibility refers to the ability of a biomaterial to perform its desired function without eliciting any undesirable biological effects [122]. For the purposes of this review, a bioprinted hydrogel must be cytocompatible and nonimmunogenic, and have nontoxic byproducts of degradation without eliciting any detrimental effects from the time of bioprinting to in vitro maturation and in vivo implantation [123]. The main factor that could influence the biocompatibility given the same material lies in the bioprinting process, which means the whole printing process needs to be cytocompatible. In most cases, bio-inks are stored as liquids in a reservoir prior to being dispensed onto the printing surface and a crosslinking process is followed to solidify the bio-inks. The cytocompatibility of this process is characterized by the cell viability test using live/dead staining [124]. To elevate the cell viability, bio-inks are designed to minimize the stress-induced damage to cells due to the sensitivity of cells encapsulated in the bio-inks. In the cases of printing mechanisms involving the use of heating or pressure, the heating temperatures are kept within the range favoring cell survival and the pressure is maintained as low as possible.

\subsection{Printability}

Printability of a bio-ink, once printed in a layer-by-layer fashion, is its ability to form and maintain a structure as designed with structural fidelity and integrity. Printability is considered to be associated with surface tension, viscosity, rheological properties, and crosslinking mechanisms. Standardized tests to quantify the printability still do not exist, and an optical examination method is usually adopted to do a geometry comparison (e.g., pore size, fiber diameter) between generated constructs and CAD data $[125,126]$.

\subsubsection{First-Layer Formation}

The printing and formation of the first layer of bio-inks play an important role for fabricating the whole construct. A relatively large contact angle between dispensed bio-inks and the substrate help to maintain the vertical dimension of printed bio-inks and avoid the flattening of the printed hydrogel precursor solution. The interaction between printed bio-inks and substrate is crucial, since suitable interaction helps to anchor the whole bioprinted construct on the printing surface and avoids possible deformation and undesired movement during the layer-by-layer bio-inks deposition process. Unfortunately, most receiving surfaces such as glass or plastic have poor contact angles with bio-inks and it is difficult to establish any interaction between receiving surface and dispensed bio-inks. These issues could be addressed by either printing hydrogels in a hydrophobic high-density fluid, such as perfluorotributylamine [78], or coating a thin layer of chemicals, such as 3-(trimethoxysilyl) propyl methacrylate, on the printing surface [127] to enhance their hydrophobicity. Polyethylenimine was used successfully in our group to pre-treat the culture plates to establish an electrostatic interaction between printed cell-laden hydrogel and the receiving surface [128].

\subsubsection{Viscosity}

Viscosity describes the internal resistance of a fluid to flow upon application of stress. The viscosity of a polymer solution is determined by its concentration, molecular weight, and temperature. Higher polymer concentration and molecular weight are associated with higher viscosity. Typically, sufficient viscosity of bio-inks leads to good printability, since it can help the bio-inks to overcome the surface-tension-driven droplet formation and be drawn to form continuous strands. Sufficient viscosity will also help the dispensed strands to maintain the cylinder shape and keep adjacent strands from merging together, which also explains why thermoplastic polymers are usually printed with higher accuracy and resolution than hydrogels. However, cells thrive best in an aqueous environment, 
in which their matrix deposition is not limited by the dense polymer network [129]. Bio-inks with high viscosity require high pressure to expel them out of the dispensing needle; in this case, the embedded cells are exposed to a high shear force, which may impair cell viability [130].

The viscosity of a bio-ink solution is mainly determined by the polymer concentration and molecular weight. Given that bio-inks with high concentrations may not be favorable for cell proliferation/migration and ECM formation [129], it is reasonable to choose low concentrations of high molecular weight polymers for better printability in bioprinting. This also explains the success of natural polymers in the bioprinting area.

\subsubsection{Shear Thinning}

Shear thinning is another desirable feature for bio-inks that will help to improve the printability, and it refers to the fact that viscosity decreases as shear rate increases [131]. Polymer solutions with higher concentrations show more obvious shear thinning. When bio-inks are exposed to high shear rates inside a nozzle during bioprinting, a decreased viscosity or shear stress will be present, which favors the survival of embedded cells. Meanwhile, a sudden decrease of shear rates upon deposition causes a sharp increase in viscosity, resulting in a high printing fidelity.

\subsubsection{Crosslinking Mechanisms}

The printability is also influenced by how easily and efficiently materials can be crosslinked. EBB usually requires printing a cell-laden polymer solution followed by initiating gelation immediately after extrusion. The cell-laden polymer solution must be either prepared quite viscous or crosslinked rapidly after dispensing onto the printing surface to achieve good printability and shape fidelity. However, high viscosity is not ideal for its application in TE and impedes cells survival and proliferation $[132,133]$. Therefore, a relatively rapid crosslinking process is usually desirable in the printing process. Currently, ionic, photo, and thermal crosslinking are most commonly used crosslinking mechanisms in bioprinting (Table 2).

\subsection{Strategies to Strengthen Mechanical Properties of Engineered Cartilage Construct}

Engineered cartilage should maintain sufficient mechanical properties after bioprinting to provide embedded cells with a stable environment for attachment, proliferation, and differentiation. Particularly for cartilage bioprinting in CTE, mechanical properties are crucial because the functions of cartilage mainly rely on their mechanical performance. Mechanical properties of hydrogel are intrinsically weak compared to cartilage [134]. Strategies have been developed to strengthen the initial mechanical performance of engineered constructs.

Research has supplemented hydrogel with mineral particles (e.g., hydroxyapatite) to create composite hydrogels, by combining organic and inorganic phases to obtain desirable properties including the improvement of mechanical properties and enhancement of biological properties $[135,136]$. In CTE, the presence of calcium phosphate has been shown to promote chondrocyte hypertrophy and Collagen type $X$ deposition and thus improve the regeneration of calcified cartilage [30,137]. Moreover, hydroxyapatite would be a good supplement in scaffolding materials in CTE to recruit endogenous cells in vivo to regenerate articular surface without cell transplantation [138].

A novel approach reinforced hydrogel constructs by incorporating printed polycaprolactone (PCL) scaffolds. Hydrogel precursors were poured and perfused into the printed porous PCL scaffold and crosslinked. In this way, the stiffness of the resulting constructs could be tailored to that of native cartilage by reinforcement with high-porosity PCL scaffolds [139]. Fabricating cartilage constructs by alternating printing injected-printed hydrogels and electrospun thermoplastic polymer fibers is also feasible [108]. It would be a promising technique if electrospun thermoplastic polymer fibers can be incorporated into EBB to print constructs with native mechanical characteristics.

A higher mechanical strength can also be achieved by blending multiple polymers and varying the molar ratio of bio-ink components. From instance, nanocellulose and alginate composite bio-ink 
was synthesized and printed to fabricate chondrocyte-laden constructs. Increasing the alginate fraction in bio-ink formula would lead to an increase in compressive modulus of printed constructs [34].

Making use of the crosslinking mechanism is also an efficient way to enhance the mechanical properties of the printed constructs. For example, a three-step method was used to crosslink alginate hydrogel for improved elastic stiffness; furthermore, the three steps are the primary calcium ionic cross-linking to increase the initial viscosity of alginate, secondary calcium ionic crosslinking to solidify the printed structure, and tertiary barium ionic crosslinking to strengthen elastic stiffness [140].

Another effective way to enhance the mechanical properties is the use of hybrid bioprinting to co-deposit hydrogels and thermoplastic polymers alternately. Cell-laden hydrogels are supported by printed thermoplastic polymers; thus, these hybrid constructs possess mechanical characteristics that are mainly provided by the printed thermoplastic polymer frame, which is significantly higher than the hydrogel-only constructs [141]. Meanwhile, by designing and changing the architecture of the thermoplastic polymer framework parameters, including molecular weight of polymer, strand size, strand spacing, and strand orientation, the mechanical properties of the construct can be tuned [142]. A covalent bonding based on methacrylate groups between thermoplastic polymer methacrylated poly(hydroxymethylglycolide-co-e-caprolactone)/PCL (pHMGCL/PCL) and gelatin methacrylamide (GelMA) hydrogel can also be established to improve binding in the interface of two materials and further elevate the mechanical performance of the engineered construct [29].

If a scaffold is designed to initially promote engineered tissue formation in vitro prior to implantation in vivo, then they are not required to exactly match the mechanical properties of natural cartilage at the initial stage. Thereby, many hydrogel-based cartilage bioprinting research still focus on formulating bio-inks to favor the synthesis of cartilaginous ECM instead of their initial mechanical strength with the hope that the ECM generated by the cells in vitro provides sufficient mechanical properties upon implantation in vivo.

\section{Cartilage Constructs Bioprinting Approaches}

Current cartilage constructs are mainly printed based on two approaches: (i) direct printing of cartilage constructs from bio-inks (called the self-supporting hydrogel bioprinting) and (ii) alternating printing of bio-inks and thermoplastic-polymer network (called the hybrid bioprinting). The advantages of self-supporting hydrogel bioprinting rests on their mild and physiological crosslinking conditions and its relatively simple process as compared to hybrid bioprinting. However, the self-supporting bioprinting requires a high level of printability of bio-inks and the printed hydrogel constructs typically have week mechanical properties [128]. In contrast, the thermoplastics network printed in hybrid bioprinting can offer a sufficient mechanical support to the subsequently dispensed hydrogel strands for being crosslinked. Therefore, hybrid bioprinting can print a broader range of bio-inks than self-supporting hydrogel bioprinting. Nevertheless, the high temperature for melting thermoplastic polymers in hybrid bioprinting may impair cell viability. Additionally, hybrid bioprintng may introduce extra printing errors due to its complex process and heating-related stresses within printed constructs [143].

\subsection{Self-Supporting Hydrogel Bioprinting}

Self-supporting hydrogel bioprinting approaches form cartilage constructs for CTE application by printing stem cell- or chondrocyte-laden natural and synthetic hydrogels [144]. Chondrocytes and stem cells embedded within alginate hydrogels has been demonstrated to be viable and metabolically active [145]. Rapid crosslinking makes alginate a commonly used component in bio-inks to print cartilage constructs. A highly printable bio-ink consisted of alginate and nanocellulose was formulated. The printed constructs supported the culture of human nasoseptal chondrocytes and had the potential to be printed into more complex shapes [34]. Alginate has also been sulfated to bind growth factors such as fibroblast growth factor (FGF), transforming growth factor (TGF) without losing its printability [146,147]. A chondrocyte-laden construct consisting of sulfated alginate and nanocellulose still provided good 
printability and Collagen type II deposition $[148,149]$. Lack of sufficient cell adhesion sites still limits the application of alginate in CTE. By incorporating BioCartilage (cartilage extracellular matrix particles) and gellan in alginate, the bioactivity and printability of the bio-ink was significantly improved and the resulting patient-specific cartilage grafts showed good mechanical property and biological properties [27].

Hyaluronic acid (HA), as an essential component of cartilage ECM, can mediate cellular signaling, wound repair, and ECM organization due to its structural and biological properties [150]. More recently, HA is increasingly explored as a "building block" in various bio-inks formulations for cartilage bioprinting in CTE because of its viscoelastic and bioactive properties [151]. Nevertheless, one major drawback of unmodified HA for cartilage bioprinting is the poor stability owing to its water solubility. To address the problem of the poor stability of printed HA, the photo-crosslinkable dextran derivate or acrylated Pluronic was added to improve mechanical properties and the printability of the material. Moreover, embedded chondrocytes demonstrated good compatibility with this bio-inks formulation [152,153].

Although gelatin gel has been shown to support chondrocyte viability and differentiation, its low viscosity and de-crosslinking at $37{ }^{\circ} \mathrm{C}$ make it hard to print [154]. Therefore, gelatin is usually modified to become photo-crosslinkable by a straightforward reaction with an acrylate or methacrylate agent [72,155]. For example, a study [102] explored the functionalization, preparation and use of cell-laden gelatin methacryloyl (GelMA)-based hydrogels as modular tissue culture platforms. For improved printability of gelatin, HA was also incorporated in GelMA and printed chondrocyte-laden constructs supported the viability of embedded chondrocytes and cartilaginous tissue formation [50].

Acrylation is also commonly used with synthetic hydrogels to facilitate cartilage bioprinting. An example is printing poly (ethylene glycol) dimethacrylate (PEGDMA) together with human chondrocytes to repair defects with osteochondral plugs through a layer-by-layer manner. The printed construct showed a higher mechanical property of $395.73 \mathrm{kPa}$ than most printed natural hydrogels. This study demonstrated that hydrogel bioprinting is a feasible approach of producing cartilage constructs with anatomic characteristics to accurate targeted locations. The embedded human chondrocyte viability was $89 \%$ and showed an elevated glycosaminoglycan (GAG) content. Additionally, printed cartilage constructs firmly attached to the surrounding tissue and showed even greater proteoglycan deposition at the interface of implant and native cartilage [48].

Improving the integrity between the engineered cartilage and subchondral bone remains a challenge. In this regard, a self-supporting hydrogel construct was printed onto the printed bone paste (consisting of demineralized bone matrix and powdered gelatin) to mimic the cartilage and subchondral bone respectively [156]. Heterogeneous cell-laden high-viscosity alginate hydrogel constructs were printed with distinct parts for human chondrocytes and osteogenic progenitors for potential use as osteochondral grafts. Embedded cells stayed in their compartment of the printed scaffold for the whole culture period and viability remained high throughout the printing and culture process and cartilage and bone ECM formation were observed both in vitro and in vivo [157]. The reported cartilage constructs fabricated by self-supporting hydrogel bioprinting are summarized in Table 3.

To sum up, self-supporting hydrogel bioprinting of cartilage constructs can be processed under cytocompatible conditions and printed constructs are generally shown to support cartilage ECM biosynthesis. Current research emphasis is focused on formulating bio-inks to achieve high printability and improving the mechanical performance of printed constructs. The relatively weak mechanical properties of printed hydrogel-based cartilage constructs limit its application to regenerating focal cartilage defects, where most exerted force is born by its surrounding tissue. To overcome these issues, hybrid cartilage bioprinting by alternating printing of bio-inks and thermoplastic polymers fibers (hybrid bioprinting) has been brought forward. 
Table 3. Overview of publications on the self-supporting hydrogel bioprinting of (osteo) chondral and zonally organized cartilage regenerative constructs.

\begin{tabular}{|c|c|c|c|c|c|}
\hline Material(s) & Cell Type(s) & Mechanical Properties & $\begin{array}{c}\text { Crosslinking } \\
\text { Mechanism(s) }\end{array}$ & Outcomes & Reference \\
\hline \multicolumn{6}{|c|}{ Hydrogel Bioprinting of Chondral Constructs } \\
\hline Alginate & $\begin{array}{l}\text { ATDC } 5 \text { chondrogenic } \\
\text { cell line and embryonic } \\
\text { chick chondrocytes }\end{array}$ & $\begin{array}{l}\text { Unconfined compressive modulus: } \\
20 \sim 70 \mathrm{kPa} \text { (depending on the culture } \\
\text { time and crosslinking densities) }\end{array}$ & Ionic & $\begin{array}{l}\sim 85 \% \text { cell viability, show cartilage } \\
\text { extracellular matrix formation in constructs }\end{array}$ & [128] \\
\hline Nanocellulose with alginate & $\begin{array}{l}\text { Human nasoseptal } \\
\text { chondrocytes }\end{array}$ & $\begin{array}{l}\text { Unconfined compressive modulus: } \\
75 \sim 250 \mathrm{kPa} \text { (depending on the ratio } \\
\text { of two materials) }\end{array}$ & Ionic & $73-86 \%$ cell viability & [34] \\
\hline $\begin{array}{l}\text { Methacrylated chondroitin sulfate (CSMA) } \\
\text { with a triblock copolymer poly (N-(2- } \\
\text { hydroxypropyl)methacrylamide-mono/dilactate) }\end{array}$ & $\begin{array}{l}\text { ATDC5 chondrogenic } \\
\text { cell line }\end{array}$ & $\begin{array}{l}\text { Unconfined compressive modulus: } \\
7-60 \mathrm{kPa} \text { (depending on the degree } \\
\text { of methacrylation) }\end{array}$ & Photo & $\sim 95 \%$ cell viability & {$[158]$} \\
\hline GelMA with gellan gum & $\begin{array}{l}\text { ATDC5 chondrogenic } \\
\text { cell line }\end{array}$ & $\begin{array}{l}\text { Unconfined compressive modulus: } \\
18-59 \mathrm{kPa} \text { (depending on the } \\
\text { concentration of gellan gum) }\end{array}$ & $\begin{array}{l}\text { Ionic, photo and } \\
\text { thermal }\end{array}$ & $\begin{array}{l}\text { Approximately } 50 \% \text { cell viability in plotted } \\
\text { gels due to the supraphysiological } \\
\text { temperature of } 40-50^{\circ} \mathrm{C} \text {. }\end{array}$ & {$[94,159]$} \\
\hline GelMA with gellan gum & $\begin{array}{l}\text { Equine articular } \\
\text { chondrocytes }\end{array}$ & $\begin{array}{l}\text { Unconfined compressive modulus: } \\
2.7-186 \mathrm{kPa} \text { (depending on ratio and } \\
\text { content of two components) }\end{array}$ & $\begin{array}{l}\text { Ionic, photo and } \\
\text { thermal }\end{array}$ & $\begin{array}{l}\text { Support cartilage matrix production, } \\
\text { higher gellan gum contents improves the } \\
\text { printability but compromise cartilage ECM, } \\
\text { and high total polymer concentrations } \\
\text { hamper the distribution of ECM. }\end{array}$ & {$[94,159]$} \\
\hline Fibroin and gelatin & $\begin{array}{l}\text { Human mesenchymal } \\
\text { stem cells, Human } \\
\text { articular chondrocytes }\end{array}$ & Not reported & Enzymatic & $\begin{array}{l}84-90 \% \text { cell viability of both cell types } \\
\text { during } 14 \text { days of culture, supported } \\
\text { cartilage ECM deposition and remodeling, } \\
\text { minimize hypertrophic differentiation } \\
\text { towards development and promote } \\
\text { cartilage development. }\end{array}$ & [73] \\
\hline $\begin{array}{l}\text { Hydroxyethyl methacrylate derivatized dextran } \\
\text { (Dex-HEMA) and hyaluronic acid (HA) }\end{array}$ & $\begin{array}{l}\text { Equine articular } \\
\text { chondrocytes }\end{array}$ & $\begin{array}{l}\text { Ultimate compressive stress: } \\
\text { 100-160 kPa (depending on the HA } \\
\text { content), uncontained compressive } \\
\text { modulus: } 26 \mathrm{kPa} \text { for different } \\
\text { constructs }\end{array}$ & Photo & $\begin{array}{c}\text { Cell viabilities are } 94 \% \text { and } 75 \% \text { after day } 1 \\
\text { and day } 3\end{array}$ & [153] \\
\hline $\begin{array}{c}\text { Diacrylated Pluronic F127 and } \\
\text { methacrylated HA }\end{array}$ & $\begin{array}{l}\text { Bovine articular } \\
\text { chondrocytes }\end{array}$ & $\begin{array}{l}\text { Unconfined compressive modulus: } \\
1.5-6.5 \mathrm{kPa} \text { (depending on the } \\
\text { methacrylated HA content) }\end{array}$ & Photo & Cell viability is between $60 \%$ to $85 \%$. & [152] \\
\hline $\begin{array}{l}\text { GelMA constructs reinforced with } \\
\text { methacrylated pHMGCL/PCL }\end{array}$ & $\begin{array}{l}\text { Human articular } \\
\text { chondrocytes }\end{array}$ & $\begin{array}{l}\text { Unconfined compressive failure } \\
\text { force } \sim 2.7 \mathrm{~N} \text { and } \sim 7.7 \mathrm{~N} \text { when } \\
\text { covalent bonds between gelMA and } \\
\text { methacrylated pHMGCL/PCL are } \\
\text { established }\end{array}$ & Photo & $\begin{array}{l}\text { Cartilage ECM network consisting of } \\
\text { GAGs and Collagen type II are formed } \\
\text { after } 6 \text { weeks of in vitro culture and } \\
\text { Collagen type II production was more } \\
\text { pronounced in vivo compared to in vitro }\end{array}$ & [29] \\
\hline
\end{tabular}


Table 3. Cont

\begin{tabular}{|c|c|c|c|c|c|}
\hline Material(s) & Cell Type(s) & Mechanical Properties & $\begin{array}{l}\text { Crosslinking } \\
\text { Mechanism(s) }\end{array}$ & Outcomes & Reference \\
\hline $\begin{array}{l}\text { Gellan, alginate and cartilage extracellular } \\
\text { matrix particles }\end{array}$ & $\begin{array}{l}\text { Bovine articular } \\
\text { chondrocytes }\end{array}$ & Tensile modulus $\sim 116-230 \mathrm{kPa}$ & Ionic and thermal & $\begin{array}{l}\text { Cell viability: } 80 \% \text { and } 96 \%, 60 \% \text { viable } \\
\text { cells are observed in the centre of some } \\
\text { samples at day } 7 \text {. Constructs with cartilage } \\
\text { ECM particles increased cartilage ECM } \\
\text { formation, but the influence of TGF- } \beta 3 \text { on } \\
\text { cartilage ECM is more pronounced and } \\
\text { constructs with TGF- } \beta 3 \text { showed most } \\
\text { cartilage ECM formation }\end{array}$ & [27] \\
\hline Methacrylated HA with HA-pNIPAAM & $\begin{array}{l}\text { Bovine articular } \\
\text { chondrocytes }\end{array}$ & Not reported & Thermal and photo & $\begin{array}{l}\text { Cell viability is negatively influenced by } \\
\text { the addition of HA-pNIPAAM }\end{array}$ & [28] \\
\hline \multicolumn{6}{|c|}{ Hydrogel Bioprinting of Osteochondral Constructs } \\
\hline $\begin{array}{c}\text { Alginate (cartilage) } \\
\text { Gelatin with demineralized bone matrix (bone) }\end{array}$ & Cell-free & Not reported & Ionic & $\begin{array}{l}\text { Directly printing into an osteochondral } \\
\text { defect of a bovine femur and showed good } \\
\text { geometric fidelity }\end{array}$ & [156] \\
\hline $\begin{array}{c}\text { Alginate (cartilage) } \\
\text { Alginate with biphasic calcium phosphate } \\
\text { particles (bone) }\end{array}$ & $\begin{array}{l}\text { Human articular } \\
\text { chondrocytes } \\
\text { (cartilage) } \\
\text { Human mesenchymal } \\
\text { stromal cells (bone) }\end{array}$ & $\begin{array}{l}\text { Unconfined compressive modulus: } \\
4.5-15 \mathrm{kPa} \text { (depending on porosity of } \\
\text { constructs) }\end{array}$ & Ionic & $\begin{array}{l}\text { Cell viability: } ~ 89 \% \\
\text { Cartilage and bone ECM formed in } \\
\text { designed regions of the constructs after } \\
\text { culturing for } 3 \text { weeks. In vivo tests showed } \\
\text { similar results after } 6 \text { weeks of culture }\end{array}$ & [157] \\
\hline $\begin{array}{l}\text { GelMA with gellan gum (cartilage) } \\
\text { GelMA, gellan gum and polylactic acid } \\
\text { microcarriers (bone) }\end{array}$ & $\begin{array}{l}\text { Murine mesenchymal } \\
\text { stromal cells }\end{array}$ & $\begin{array}{l}\text { Unconfined compressive modulus: } \\
\sim 25-50 \mathrm{kPa} \text { (depending on } \\
\text { concentration of microcarriers) }\end{array}$ & Photo and ionic & Cell viability: $60-90 \%$ & [93] \\
\hline \multicolumn{6}{|c|}{ Hydrogel Bioprinting of Zonally Organized Cartilage Constructs } \\
\hline Collagen type II & $\begin{array}{l}\text { Rabbit articular } \\
\text { chondrocytes }\left(2 \times 10^{7}\right. \\
\text { cells } / \mathrm{mL} \text { in superficial } \\
\text { zone, } 1 \times 10^{7} \text { cell } / \mathrm{mL} \\
\text { in middle zone and } \\
0.5 \times 10^{7} \text { cells } / \mathrm{mL} \text { in } \\
\text { deep zone })\end{array}$ & Not reported & Thermal & $\begin{array}{l}\text { Cell viability: } 93 \% \text { Zonally organized } \\
\text { cartilage constructs could be fabricated by } \\
\text { bioprinting Collagen type II hydrogel } \\
\text { constructs with a biomimetic cell density } \\
\text { gradient. The cell density gradient } \\
\text { distribution resulted in a gradient } \\
\text { distribution of ECM }\end{array}$ & [49] \\
\hline
\end{tabular}




\subsection{Hybrid Bioprinting}

A hybrid construct combining advantages of hydrogel and thermoplastics has been brought forward, offering potential for application in CTE [141]. Scaffolds made from thermoplastic polymers provide stronger structural properties, and hydrogels provide a biologically favorable, highly hydrated microstructure like native cartilage ECM for chondrocytes. By alternately printing thermoplastic polymer and cell-laden hydrogel, hybrid cartilage construct is yielded. This mechanism makes a broader range of bio-inks types available for use compared to bioprinting of hydrogels alone, since requirements for viscosity and gelling speed are less stringent [141]. Additionally, engineered cartilage fabricated by hybrid bioprinting possesses adequate mechanical characteristics, since the thermoplastic polymer framework mainly provides the mechanical property of the constructs [141].

By applying this state-of-the-art printing technology, human nasoseptal chondrocyte-laden alginate hydrogel with a supportive PCL structure was printed [33]. The study demonstrated in vitro and in vivo applications of hybrid constructs encapsulating chondrocytes and growth factors in CTE. Another trial explored the feasibility to use embryonic chick chondrocytes as cell sources for hybrid printing and comprehensively studied biological performance of the embedded chondrocytes. Cell viability, proliferation, and cartilage ECM biosynthesis were all kept at high levels in hybrid constructs, confirming the validity of the hybrid bioprinting for effective CTE [160]. Given the bioinert nature of alginate, it is not an ideal material for encapsulating chondrocytes and maintaining their functionality. Therefore, a study printed hybrid tissue analogues by dispensing decellularized ECM (dECM) instead of alginate in the abovementioned hybrid bioprinting system. The results showed the versatility and flexibility of hybrid bioprinting process using various tissue-specific dECM bio-inks, including adipose, cartilage and heart tissues, which can provide bioactive cues for embedded cells [143].

Hybrid bioprinting also showed good suitability to fabricate osteochondral constructs, enabling researchers to use different bio-inks in cartilage portion and bone portion. A mechanically stable 3D dual cell-laden construct consisting of osteoblasts and chondrocytes for osteochondral tissue engineering using a multi-head extrusion-based printing system was successfully printed. Two different alginate solutions with encapsulated osteoblasts or chondrocytes were deposited into the previously printed PCL framework [161]. A more recent study from the same research group successfully bioprinted a multilayered construct with three distinct layers by varying the hydrogel materials and incorporated growth factors using a similar hybrid printing process and achieved the regeneration of osteochondral defects in the knee joints of rabbits [162]. Overviews of hybrid bioprinting for fabricating osteo (chondral) constructs reviewed in Table 4.

These studies show the promise of hybrid bioprinting as an advanced fabrication technique for CTE. However, mechanical stimuli exerted on hybrid construct would probably be mainly withstood by the polymeric scaffolds instead of chondrocyte-laden hydrogel because of stress shielding [163]. This might be an issue when considering mechanical stimuli can positively mediate chondrocytes biosynthetic behavior [164] and cartilage tissue remodeling [165]. Therefore, further studies need to be carried out to determine the influence of mechanical stimuli on the engineered hybrid constructs. 
Table 4. Overview of publications on the hybrid bioprinting of osteo (chondral) constructs.

\begin{tabular}{|c|c|c|c|c|c|}
\hline Material(s) & Cell Type(s) & Mechanical Properties & $\begin{array}{l}\text { Crosslinking } \\
\text { Mechanism(s) }\end{array}$ & Outcomes & Reference \\
\hline \multicolumn{6}{|c|}{ Hybrid Bioprinting of Chondral Constructs } \\
\hline $\begin{array}{l}\text { Alginate reinforced with } \\
\text { polycaprolactone (PCL) framework }\end{array}$ & C20A4 human chondrocyte cell line & $\begin{array}{l}\text { Unconfined compressive } \\
\text { modulus: } 6000 \mathrm{kPa}\end{array}$ & Ionic & $\begin{array}{l}\text { Cell viability varies from } 70 \text { to } 80 \% \text {. Co-deposition of } \\
\text { thermoplastic polymer and hydrogel is firstly } \\
\text { introduced for bioprinting of reinforced constructs. }\end{array}$ & [141] \\
\hline $\begin{array}{l}\text { Alginate reinforced with } \\
\text { PCL framework }\end{array}$ & Human nasoseptal chondrocytes & Not reported & Ionic & $\begin{array}{l}85 \% \text { cell viability, cartilage ECM formation in } \\
\text { constructs with the addition of TGF- } \beta \text { after culturing } \\
\text { for } 4 \text { weeks. Cartilage ECM formation is observed in } \\
\text { constructs with after } 4 \text { weeks in vivo. }\end{array}$ & [33] \\
\hline $\begin{array}{l}\text { Alginate reinforced with } \\
\text { PCL framework }\end{array}$ & Embryonic chick chondrocytes & Not reported & Ionic & $\begin{array}{l}\text { Cell viability: } 77-85 \% \text {; Cartilage ECM } \\
\text { (glycosaminoglycan and Collagen type II) is formed } \\
\text { in constructs. }\end{array}$ & {$[160]$} \\
\hline $\begin{array}{l}\text { Decellularized extracellular matrix } \\
\text { (dECM) reinforced with } \\
\text { PCL framework }\end{array}$ & $\begin{array}{l}\text { Human adipose-derived stem cells } \\
\text { (hASCs) and human inferior } \\
\text { turbinate-tissue derived } \\
\text { mesenchymal stromal cells } \\
\text { (hTMSCs) }\end{array}$ & Not reported & Thermal & $\begin{array}{l}\text { Cell viability: }>90 \% \text {. The dECM provided cues for cells } \\
\text { survival and long-term functionality. Embedded cell } \\
\text { synthesizes cartilage ECM and expressed } \\
\text { chondrogenic genes. }\end{array}$ & [143] \\
\hline \multicolumn{6}{|c|}{ Hybrid Bioprinting of Osteochondral Constructs } \\
\hline $\begin{array}{l}\text { Alginate reinforced with } \\
\text { PCL framework }\end{array}$ & $\begin{array}{l}\text { Human nasoseptal chondrocytes } \\
\text { (cartilage) Human osteoblasts cell } \\
\text { line (MG63) }\end{array}$ & Not reported & Ionic & $\begin{array}{l}\text { Cell viability: } \sim 93.9 \% \text { for dispensed chondrocytes and } \\
\sim 95.6 \% \text { for dispensed osteoblasts during } 7 \text { days } \\
\text { of culture. }\end{array}$ & [161] \\
\hline $\begin{array}{c}\text { Atelocollagen supplemented with } \\
\text { BMP-2 (cartilage) CB[6]-HA } \\
\text { supplemented with TGF- } \beta \text { (bone) } \\
\text { The whole structure is reinforced } \\
\text { with PCL framework }\end{array}$ & $\begin{array}{l}\text { Human turbinate-derived } \\
\text { mesenchymal stromal cells } \\
\text { (hTMSCs) }\end{array}$ & Not reported & Thermal and enzymic & $\begin{array}{l}\text { Cell viability: } 93 \% \text { for atelocollagen (bone) and } 86 \% \text { CB } \\
\text { (6)-HA (cartilage). In vivo results showed neocartilage } \\
\text { is formed in cartilage region while new bone is } \\
\text { observed in subchondral bone. The constructs are well } \\
\text { integrated with surrounding native tissue in vivo. }\end{array}$ & [162] \\
\hline
\end{tabular}




\section{Zonal Cartilage Bioprinting}

Zonal cartilage constructs that reflect the native structural depth-dependent characteristics of articular cartilage could have advantages over homogeneous constructs. A zonal cartilage construct can be achieved by the following strategies: (1) using zonal chondrocyte subpopulations from different zones of cartilage; (2) using a single cell source combined with the correct biochemical and/or biomechanical cues; (3) using different biomaterials and smart scaffold designs. Zonal chondrocyte subpopulations from different zones of cartilage tissue can be harvested [1,166,167], but donor site morbidity, dedifferentiation during expansion, and limited availability are the drawbacks of this strategy. Meanwhile, there is still a debate if zonal chondrocytes can maintain their phenotype after being isolated from their original biomechanical and biochemical environment [31]. Comparing with Strategy (1), Strategy (2) might be an easier and more practical technique using single cell source combined with the suitable biochemical and/or biomechanical cues. BMSCs have been induced to differentiate into zonal chondrogenic cells by co-culturing with various molecules [168-170]. This method shows great promise since it would be easier to carry out and potentially could solve the problems associated with direct isolating zonal chondrocytes from cartilage. A good example of Strategy 3 was reported by Wise et al. [171]. They successfully mimicked the cells and ECM organization found in the superficial zone by culturing BMSCs on electrospun and oriented PCL scaffolds. Bio-inks can be formulated based on these strategies for the fabrication of complex zonal structures. Technically, zonal cartilage bioprinting can be realized either by self-supporting hydrogel bioprinting or hybrid bioprinting (Figure 2). It has been reported that zonal engineered cartilage could be fabricated by bioprinting Collagen type II hydrogel constructs with a biomimetic cell density gradient [49]. Even though, zonal cartilage bioprinting is still a challenging task because of the complexity of fabrication process, involving multiple bio-inks preparation, frequent switching between dispensing heads, and complicated real-time calibration.

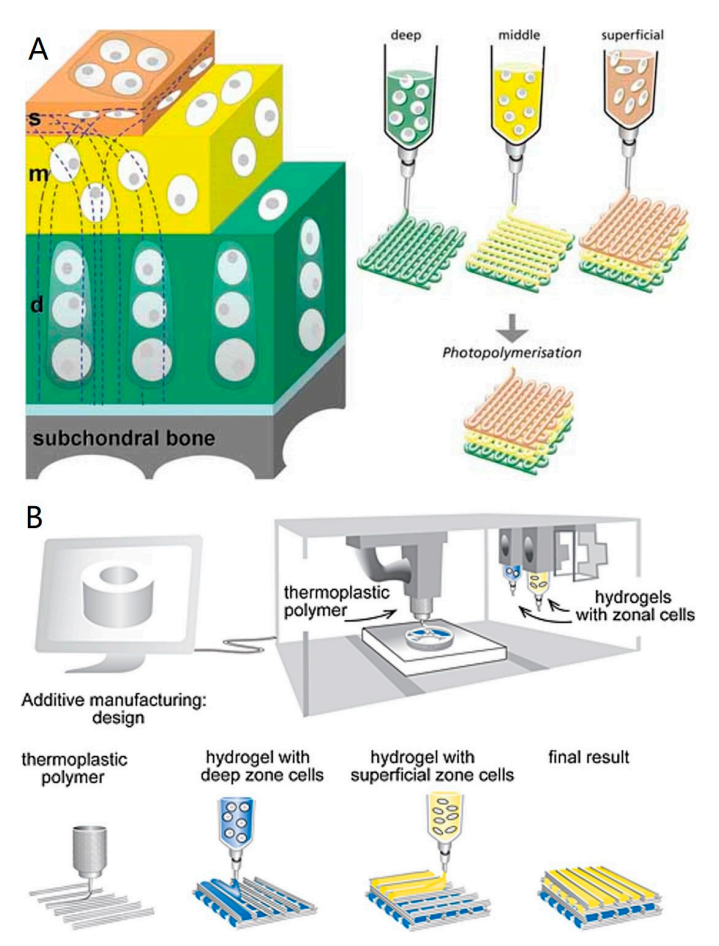

Figure 2. (A) Schematic of self-supporting hydrogel bioprinting for fabrication of zonal cartilage constructs. Zonal constructs are printed with chondrocytes from the superficial, middle, and deep zones incorporated in distinct hydrogel precursors in defined geometries. Reproduced with permission. Copy right 2009, Wiley Online Library [144]; (B) Schematic of hybrid bioprinting for fabrication of zonal cartilage constructs. Alternating steps of printing polymer and zonal cell-laden hydrogels are performed to obtain zonal constructs Reproduced with permission. Copyright 2015, Wiley Online Library [31]. 


\section{Current Limitations and Recommendations for Future Research}

EBB is a convenient and promising technique that can print porous tissue-engineered constructs with structural and biological properties from a wide range of bio-inks. It still has several limitations, including limited biomaterials for bio-ink formulation, cell death during printing, low resolution as well as insufficient mechanical properties. Bio-inks formulation is restricted by limited printable biomaterials, which makes up only a small portion of biomaterials applied in TE. To alleviate this problem, development of new biomaterials for bio-ink formulation is needed. When formulating and processing new bio-inks, the properties discussed in Section 3 should be considered and/or compromised for a given CTE application. Further, for clinic application, bio-inks must also satisfy the requirements and regulations as set in standards and norms. Unfortunately, such standards and norms are few nowadays and even none are directly related to bioprinted implants for TE, which raises a great need for such standards and norms [172]. Cell death during the printing process is usually caused by the process-induced forces, such as shear stress, exerted on cells $[173,174]$. This happens especially when the bio-ink is highly viscous, in which cells would experience significantly higher shear stress [175]. Meanwhile, high viscosity possibly induces clogging of the nozzle tip, leading to disturbance of the printing process [176-178]. However, relatively high viscosity is essential for the bio-inks to be dispensed into undisrupted strands with higher resolution and printing accuracy. A recent study printed hydrogels in liquid nitrogen to fabricate scaffolds with high resolution and precisely defined dimensions [179]. However, it impaired the cell viability when printing with cell-laden hydrogels. Therefore, a compromise is usually needed to be made among these factors. Future studies should also focus on new approaches to improve the printability of bio-inks without negatively influencing the cell behavior. Research should also be implemented on developing new techniques to process bio-inks prior to printing to improve printability. For example, increased mixing of alginate and cross-linker solutions actually improved geometric fidelity, mechanical properties, and cell viability of printed constructs [180-182].

Other printing parameters, including printing pressure, nozzle geometry and diameter, and bio-ink concentration, have also been shown to influence cell viability within bio-inks $[72,130]$. Manipulating and optimizing these process parameters can potentially address these issues and challenges to some extent. Recent finding also demonstrated the influence of these printing parameters on printing accuracy [183]. Therefore, we urge that future studies should indicate these parameters when investigating new bio-inks to improve consistency and repeatability.

To fabricate functional cartilage construct, suitable cell sources, biological cues, and construct organization are still needed to be determined for successful cartilage regeneration. Most present studies only focus on evaluating cell viability in different bioprinted hydrogels, while functionality of the engineered cartilage is not very well characterized. As such, we also urge that, for bioprinted engineered cartilage constructs, research should also emphasize the overall chondrogenesis within the constructs, either qualitatively (e.g., Alcian Blue and Safranin O histology) or quantitatively (e.g., collagen and glycosaminoglycan content, or aggrecan and Collagen type II gene expression). Moreover, given that the mechanical performance of cartilage engineered from hydrogel is usually inferior to native cartilage, research on mechanical properties is also required for future cartilage bioprinting studies. Notably, current mechanical characterization of engineered cartilage constructs is mainly performed based on a single mechanical test (Table 4). However, a single acceptable mechanical test result does not sufficiently prove the engineered constructs can perform its biomechanical functions as good as native cartilage tissue. Therefore, a series of mechanical tests (e.g., compression, tensile, and shear tests) needs to be done to comprehensively characterize the mechanical performance of bioprinted cartilage constructs [184].

Theoretically, the shape of scaffolds fabricated by bioprinting techniques can match personalized defects in vivo. Notably, current in vivo research is usually based on man-made regular defects, which can be made fitting with a bioprinted scaffold with exact shape and dimension. It could be difficult for the in vitro printed material to match perfectly with the defect that needs to be regenerated. Printed 
construct could deform during in vitro culture and defects may expand while waiting for implantation. Although defined defects can be created in clinic, this is not desirable since it further increases the area that needs to be regenerated. Therefore, the concept of "in situ" bioprinting has been performed to directly print alginate hydrogels into a defect on an explanted articular surface from a calf [156]. This strategy avoids laboratory-based constructs culture and multiple surgical intervention and would represent the future of TE using bioprinting techniques for cartilage regeneration.

Issues facing CTE is the inability to translate technologies into the clinic and lack of clinic standards of materials for human tissue biopriting [185]. To move bioprinted living cartilage implants into clinic application, bio-inks also must satisfy the requirements and regulations on safety, sterility, and reproducibility. To ensure safety of bioprinted implants for clinical application and to help researchers qualify and validate the bioprinting process and bio-ink formulations, consistent standards are required. Additive manufacturing standards have been published by American Society for Testing and Materials (ASTM) F2792. Meanwhile, standards for tissue-engineered constructs have been approved by the ASTM international committee F04, the International Organization for Standardization technical committee 150/SCZ, and the British Standards Institute. Nevertheless, there are no standards is currently available for bioprinted implants applied in TE field [172]. To ensure sterility throughout bioprinting, the process has to be incorporated in a Good Manufacturing Practice facility, and all components of bioprinter should be sterile and can be operated in a sterile environment. Moreover, the whole bioprinting process should involve minimal manual handling and operation. Therefore, skilled operators are needed to monitor the printing process. Automated, reliable quality control during the printing process will also promote the translation of printers into clinics. Having an integrated bioreactor system with bioprinters to allow in vitro culture before implantation is also an efficient way to avoid undesirable handling of the printed construct and to improve the sterility and reproducibility.

\section{Conclusions}

EBB is an advanced fabrication technique to produce customized cell-laden hydrogel-based constructs for CTE so as to mimic chondral, osteochondral, and zonal organization of articular cartilage. Despite the advantages and opportunities provided by hydrogel-based EBB for cartilage bioprinting, there are still multiple challenges that need to be addressed. Bio-inks for EBB need to be synthesized and optimized in terms of their biocompatibility, formulation, processing, printability, and optimal cell sources. Self-supporting hydrogel bioprinting and hybrid bioprinting are two common approaches to fabricate cartilage constructs. The former technique provides a cell-friendly printing environment but limited mechanical strength, while the latter brings elevated mechanical properties but the stress shielding may disable external mechanical stimuli. Tackling the challenges revolving around bio-inks and mechanical performance of resulting cartilage constructs will foster biologically active and living bioprinted implants for future clinical applications.

Acknowledgments: The authors acknowledge financial support from the China Scholarship Council (CSC, 201306240046), Saskatchewan Health Research Foundation (SHRF Reference \# 2784), and Natural Sciences and Engineering Research Council of Canada (NSERC RGPIN-2014-05648).

Author Contributions: Fu You, B. Frank Eames, and Xiongbiao Chen conceived the idea of this review article; Fu You drafted the article; B. Frank Eames and Xiongbiao Chen provided critical revision of the article.

Conflicts of Interest: The authors declare no conflict of interest.

\section{References}

1. Klein, T.; Schumacher, B.; Schmidt, T.; Li, K.; Voegtline, M.; Masuda, K.; Thonar, E.J.-M.A.; Sah, R.L. Tissue engineering of stratified articular cartilage from chondrocyte subpopulations. Osteoarthr. Cartil. 2003, 11, 595-602. [CrossRef]

2. O'Driscoll, S.W. The healing and regeneration of articular cartilage. J. Bone Jt. Surg. Am. 1998, 80, $1795-1812$. [CrossRef] 
3. Drury, J.L.; Mooney, D.J. Hydrogels for tissue engineering: Scaffold design variables and applications. Biomaterials 2003, 24, 4337-4351. [CrossRef]

4. Hutmacher, D.W. Scaffolds in tissue engineering bone and cartilage. Biomaterials 2000, 21, $2529-2543$. [CrossRef]

5. Fedorovich, N.E.; Alblas, J.; de Wijn, J.R.; Hennink, W.E.; Verbout, A.J.; Dhert, W.J. Hydrogels as extracellular matrices for skeletal tissue engineering: State-of-the-art and novel application in organ printing. Tissue Eng. 2007, 13, 1905-1925. [CrossRef] [PubMed]

6. Hoffman, A.S. Hydrogels for biomedical applications. Adv. Drug Deliv. Rev. 2012, 64, 18-23. [CrossRef]

7. Kirchmajer, D.M.; Gorkin, R., III. An overview of the suitability of hydrogel-forming polymers for extrusion-based 3D-printing. J. Mater. Chem. B 2015, 3, 4105-4117. [CrossRef]

8. Awad, H.A.; Wickham, M.Q.; Leddy, H.A.; Gimble, J.M.; Guilak, F. Chondrogenic differentiation of adipose-derived adult stem cells in agarose, alginate, and gelatin scaffolds. Biomaterials 2004, 25, 3211-3222. [CrossRef] [PubMed]

9. Benoit, D.S.; Schwartz, M.P.; Durney, A.R.; Anseth, K.S. Small functional groups for controlled differentiation of hydrogel-encapsulated human mesenchymal stem cells. Nat. Mater. 2008, 7, 816-823. [CrossRef] [PubMed]

10. Chenite, A.; Chaput, C.; Wang, D.; Combes, C.; Buschmann, M.; Hoemann, C.; Leroux, J.C.; Atkinson, B.L.; Binette, F.; Selmani, A. Novel injectable neutral solutions of chitosan form biodegradable gels in situ. Biomaterials 2000, 21, 2155-2161. [CrossRef]

11. Nicodemus, G.D.; Bryant, S.J. Cell encapsulation in biodegradable hydrogels for tissue engineering applications. Tissue Eng. Part B 2008, 14, 149-165. [CrossRef] [PubMed]

12. Schmedlen, R.H.; Masters, K.S.; West, J.L. Photocrosslinkable polyvinyl alcohol hydrogels that can be modified with cell adhesion peptides for use in tissue engineering. Biomaterials 2002, 23, 4325-4332. [CrossRef]

13. Masters, K.S.; Shah, D.N.; Leinwand, L.A.; Anseth, K.S. Crosslinked hyaluronan scaffolds as a biologically active carrier for valvular interstitial cells. Biomaterials 2005, 26, 2517-2525. [CrossRef] [PubMed]

14. Matsusaki, M.; Yoshida, H.; Akashi, M. The construction of 3D-engineered tissues composed of cells and extracellular matrices by hydrogel template approach. Biomaterials 2007, 28, 2729-2737. [CrossRef] [PubMed]

15. Yang, S.; Leong, K.; Du, Z.; Chua, C. The design of scaffolds for use in tissue engineering. Part I. Traditional factors. Tissue Eng. 2001, 7, 679-689. [CrossRef] [PubMed]

16. Bian, L.; Zhai, D.Y.; Zhang, E.C.; Mauck, R.L.; Burdick, J.A. Dynamic compressive loading enhances cartilage matrix synthesis and distribution and suppresses hypertrophy in hMSC-laden hyaluronic acid hydrogels. Tissue Eng. Part A 2011, 18, 715-724. [CrossRef] [PubMed]

17. Peltola, S.M.; Melchels, F.P.; Grijpma, D.W.; Kellomäki, M. A review of rapid prototyping techniques for tissue engineering purposes. Ann. Med. 2008, 40, 268-280. [CrossRef] [PubMed]

18. Mohan Pandey, P.; Venkata Reddy, N.; Dhande, S.G. Slicing procedures in layered manufacturing: A review. Rapid Prototyp. J. 2003, 9, 274-288. [CrossRef]

19. Mironov, V.; Trusk, T.; Kasyanov, V.; Little, S.; Swaja, R.; Markwald, R. Biofabrication: A 21st century manufacturing paradigm. Biofabrication 2009, 1, 022001. [CrossRef] [PubMed]

20. Ozbolat, I.T.; Hospodiuk, M. Current advances and future perspectives in extrusion-based bioprinting. Biomaterials 2016, 76, 321-343. [CrossRef] [PubMed]

21. Murphy, S.V.; Atala, A. 3D bioprinting of tissues and organs. Nat. Biotechnol. 2014, 32, 773-785. [CrossRef] [PubMed]

22. Sophia Fox, A.J.; Bedi, A.; Rodeo, S.A. The basic science of articular cartilage: Structure, composition, and function. Sports Health 2009, 1, 461-468. [CrossRef] [PubMed]

23. Speer, D.P.; Dahners, L. The Collagenous Architecture of Articular Cartilage: Correlation of Scanning Electron Microscopy and Polarized Light Microscopy Observations. Clin. Orthop. Relat. Res. 1979, 139, 267-275. [CrossRef]

24. Poole, A.R.; Kojima, T.; Yasuda, T.; Mwale, F.; Kobayashi, M.; Laverty, S. Composition and structure of articular cartilage: A template for tissue repair. Clin. Orthop. Relat. Res. 2001, 391, S26-S33. [CrossRef]

25. Ma, B.; Leijten, J.; Wu, L.; Kip, M.; van Blitterswijk, C.; Post, J.; Karperien, M. Gene expression profiling of dedifferentiated human articular chondrocytes in monolayer culture. Osteoarthr. Cartil. 2013, 21, 599-603. [CrossRef] [PubMed] 
26. Caron, M.; Emans, P.; Coolsen, M.; Voss, L.; Surtel, D.; Cremers, A.; van Rhijn, L.W.; Welting, T.J. Redifferentiation of dedifferentiated human articular chondrocytes: Comparison of 2D and 3D cultures. Osteoarthr. Cartil. 2012, 20, 1170-1178. [CrossRef] [PubMed]

27. Kesti, M.; Eberhardt, C.; Pagliccia, G.; Kenkel, D.; Grande, D.; Boss, A.; Zenobi-Wong, M. Bioprinting complex cartilaginous structures with clinically compliant biomaterials. Adv. Funct. Mater. 2015, 25, 7406-7417. [CrossRef]

28. Kesti, M.; Müller, M.; Becher, J.; Schnabelrauch, M.; D’Este, M.; Eglin, D.; Zenobi-Wong, M. A versatile bioink for three-dimensional printing of cellular scaffolds based on thermally and photo-triggered tandem gelation. Acta Biomater. 2015, 11, 162-172. [CrossRef] [PubMed]

29. Boere, K.W.; Visser, J.; Seyednejad, H.; Rahimian, S.; Gawlitta, D.; Van Steenbergen, M.J.; Dhert, W.J.A.; Hennink, W.E.; Vermonden, T.; Malda, J. Covalent attachment of a three-dimensionally printed thermoplast to a gelatin hydrogel for mechanically enhanced cartilage constructs. Acta Biomater. 2014, 10, 2602-2611. [CrossRef] [PubMed]

30. Khanarian, N.T.; Haney, N.M.; Burga, R.A.; Lu, H.H. A functional agarose-hydroxyapatite scaffold for osteochondral interface regeneration. Biomaterials 2012, 33, 5247-5258. [CrossRef] [PubMed]

31. Schuurman, W.; Klein, T.; Dhert, W.; Weeren, P.; Hutmacher, D.; Malda, J. Cartilage regeneration using zonal chondrocyte subpopulations: A promising approach or an overcomplicated strategy? J. Tissue Eng. Regen. Med. 2015, 9, 669-678. [CrossRef] [PubMed]

32. Chung, C.; Burdick, J.A. Engineering cartilage tissue. Adv. Drug Deliv. Rev. 2008, 60, 243-262. [CrossRef] [PubMed]

33. Kundu, J.; Shim, J.; Jang, J.; Kim, S.; Cho, D. An additive manufacturing-based PCL-alginate-chondrocyte bioprinted scaffold for cartilage tissue engineering. J. Tissue Eng. Regen. Med. 2015, 9, 1286-1297. [CrossRef] [PubMed]

34. Markstedt, K.; Mantas, A.; Tournier, I.; Martínez Ávila, H.; Hägg, D.; Gatenholm, P. 3D bioprinting human chondrocytes with nanocellulose-alginate bioink for cartilage tissue engineering applications. Biomacromolecules 2015, 16, 1489-1496. [CrossRef] [PubMed]

35. DiCarlo, B.; Hu, J.; Gross, T.; Vago, R.; Athanasiou, K. Biomaterial effects in articular cartilage tissue engineering using polyglycolic acid, a novel marine origin biomaterial, IGF-I, and TGF- $\beta$. Proc. Inst. Mech. Eng. Part H J. Eng. Med. 2009, 223, 63-73. [CrossRef] [PubMed]

36. MacBarb, R.F.; Makris, E.A.; Hu, J.C.; Athanasiou, K.A. A chondroitinase-ABC and TGF- $\beta 1$ treatment regimen for enhancing the mechanical properties of tissue-engineered fibrocartilage. Acta Biomater. 2013, 9 , 4626-4634. [CrossRef] [PubMed]

37. Hunziker, E.; Driesang, I.; Morris, E. Chondrogenesis in cartilage repair is induced by members of the transforming growth factor-beta superfamily. Clin. Orthop. Relat. Res. 2001, 391, S171-S181. [CrossRef]

38. Li, W.; Tuli, R.; Okafor, C.; Derfoul, A.; Danielson, K.G.; Hall, D.J.; Tuan, R.S. A three-dimensional nanofibrous scaffold for cartilage tissue engineering using human mesenchymal stem cells. Biomaterials 2005, 26, 599-609. [CrossRef] [PubMed]

39. Guilak, F.; Awad, H.A.; Fermor, B.; Leddy, H.A.; Gimble, J.M. Adipose-derived adult stem cells for cartilage tissue engineering. Biorheology 2004, 41, 389-399. [PubMed]

40. Andriamanalijaona, R.; Duval, E.; Raoudi, M.; Lecourt, S.; Vilquin, J.; Marolleau, J.; Pujol, J.P.; Galera, P.; Boumediene, K. Differentiation potential of human muscle-derived cells towards chondrogenic phenotype in alginate beads culture. Osteoarthr. Cartil. 2008, 16, 1509-1518. [CrossRef] [PubMed]

41. Kuroda, R.; Usas, A.; Kubo, S.; Corsi, K.; Peng, H.; Rose, T.; Cummins, J.; Fu, F.H.; Huard, J. Cartilage repair using bone morphogenetic protein 4 and muscle-derived stem cells. Arthritis Rheum. 2006, 54, 433-442. [CrossRef] [PubMed]

42. Mara, C.S.D.; Sartori, A.R.; Duarte, A.S.; Andrade, A.L.L.; Pedro, M.A.C.; Coimbra, I.B. Periosteum as a source of mesenchymal stem cells: The effects of TGF- $\beta 3$ on chondrogenesis. Clinics 2011, 66, 487-492. [CrossRef] [PubMed]

43. Kramer, J.; Hegert, C.; Guan, K.; Wobus, A.M.; Müller, P.K.; Rohwedel, J. Embryonic stem cell-derived chondrogenic differentiation in vitro: Activation by BMP-2 and BMP-4. Mech. Dev. 2000, 92, 193-205. [CrossRef] 
44. Vats, A.; Bielby, R.C.; Tolley, N.; Dickinson, S.C.; Boccaccini, A.R.; Hollander, A.P.; Bishop, A.E.; Polak, J.M. Chondrogenic differentiation of human embryonic stem cells: The effect of the micro-environment. Tissue Eng. 2006, 12, 1687-1697. [CrossRef] [PubMed]

45. Connelly, J.T.; Wilson, C.G.; Levenston, M.E. Characterization of proteoglycan production and processing by chondrocytes and BMSCs in tissue engineered constructs. Osteoarthr. Cartil. 2008, 16, 1092-1100. [CrossRef] [PubMed]

46. Meretoja, V.V.; Dahlin, R.L.; Wright, S.; Kasper, F.K.; Mikos, A.G. The effect of hypoxia on the chondrogenic differentiation of co-cultured articular chondrocytes and mesenchymal stem cells in scaffolds. Biomaterials 2013, 34, 4266-4273. [CrossRef] [PubMed]

47. Saha, S.; Kirkham, J.; Wood, D.; Curran, S.; Yang, X.B. Informing future cartilage repair strategies: A comparative study of three different human cell types for cartilage tissue engineering. Cell Tissue Res. 2013, 352, 495-507. [CrossRef] [PubMed]

48. Cui, X.; Breitenkamp, K.; Finn, M.; Lotz, M.; D’Lima, D.D. Direct human cartilage repair using three-dimensional bioprinting technology. Tissue Eng. Part A 2012, 18, 1304-1312. [CrossRef] [PubMed]

49. Ren, X.; Wang, F.; Chen, C.; Gong, X.; Yin, L.; Yang, L. Engineering zonal cartilage through bioprinting collagen type II hydrogel constructs with biomimetic chondrocyte density gradient. BMC Musculoskelet. Disord. 2016, 17, 1. [CrossRef] [PubMed]

50. Schuurman, W.; Levett, P.A.; Pot, M.W.; van Weeren, P.R.; Dhert, W.J.; Hutmacher, D.W.; Melchels, F.P.; Klein, T.J.; Malda, J. Gelatin-methacrylamide hydrogels as potential biomaterials for fabrication of tissue-engineered cartilage constructs. Macromol. Biosci. 2013, 13, 551-561. [CrossRef] [PubMed]

51. Cohen, D.L.; Malone, E.; Lipson, H.; Bonassar, L.J. Direct freeform fabrication of seeded hydrogels in arbitrary geometries. Tissue Eng. 2006, 12, 1325-1335. [CrossRef] [PubMed]

52. Van Osch, G.J.; Mandl, E.W.; Jahr, H.; Koevoet, W.; Nolst-Trenité, G.; Verhaar, J.A. Considerations on the use of ear chondrocytes as donor chondrocytes for cartilage tissue engineering. Biorheology 2004, 41, 411-421. [PubMed]

53. Yamaoka, H.; Asato, H.; Ogasawara, T.; Nishizawa, S.; Takahashi, T.; Nakatsuka, T.; Koshima, I.; Nakamura, K.; Kawaguchi, H.; Chung, U.I.; et al. Cartilage tissue engineering using human auricular chondrocytes embedded in different hydrogel materials. J. Biomed. Mater. Res. Part A 2006, 78, 1-11. [CrossRef] [PubMed]

54. Panossian, A.; Ashiku, S.; Kirchhoff, C.H.; Randolph, M.A.; Yaremchuk, M.J. Effects of cell concentration and growth period on articular and ear chondrocyte transplants for tissue engineering. Plast. Reconstr. Surg. 2001, 108, 392-402. [CrossRef] [PubMed]

55. Kafienah, W.; Jakob, M.; Démarteau, O.; Frazer, A.; Barker, M.D.; Martin, I.; Hollander, A.P. Three-dimensional tissue engineering of hyaline cartilage: Comparison of adult nasal and articular chondrocytes. Tissue Eng. 2002, 8, 817-826. [CrossRef] [PubMed]

56. Hicks, D.L.; Sage, A.B.; Schumacher, B.L.; Sah, R.L.; Watson, D. Growth and phenotype of low-density nasal septal chondrocyte monolayers. Otolaryngol. Head Neck Surg. 2005, 133, 417-422. [CrossRef] [PubMed]

57. Kafienah, W.; Mistry, S.; Dickinson, S.C.; Sims, T.J.; Learmonth, I.; Hollander, A.P. Three-dimensional cartilage tissue engineering using adult stem cells from osteoarthritis patients. Arthritis Rheum. 2007, 56, 177-187. [CrossRef] [PubMed]

58. Costantini, M.; Idaszek, J.; Szöke, K.; Jaroszewicz, J.; Dentini, M.; Barbetta, A.; Brinchmann, J.E.; Święszkowski, W. 3D bioprinting of BM-MSCs-loaded ECM biomimetic hydrogels for in vitro neocartilage formation. Biofabrication 2016, 8, 035002. [CrossRef] [PubMed]

59. Longobardi, L.; O’Rear, L.; Aakula, S.; Johnstone, B.; Shimer, K.; Chytil, A.; Horton, W.A.; Moses, H.L.; Spagnoli, A. Effect of IGF-I in the chondrogenesis of bone marrow mesenchymal stem cells in the presence or absence of TGF- $\beta$ signaling. J. Bone Miner. Res. 2006, 21, 626-636. [CrossRef] [PubMed]

60. Zuk, P.A.; Zhu, M.; Ashjian, P.; De Ugarte, D.A.; Huang, J.I.; Mizuno, H.; Alfonso, Z.C.; Fraser, J.K.; Benhaim, P.; Hedrick, M.H. Human adipose tissue is a source of multipotent stem cells. Mol. Biol. Cell 2002, 13, 4279-4295. [CrossRef] [PubMed]

61. Huang, J.I.; Kazmi, N.; Durbhakula, M.M.; Hering, T.M.; Yoo, J.U.; Johnstone, B. Chondrogenic potential of progenitor cells derived from human bone marrow and adipose tissue: A patient-matched comparison. J. Orthop. Res. 2005, 23, 1383-1389. [CrossRef] [PubMed] 
62. Bauge, C.; Boumediene, K. Use of Adult Stem Cells for Cartilage Tissue Engineering: Current Status and Future Developments. Stem Cells Int. 2015, 2015, 438026. [CrossRef] [PubMed]

63. Nawata, M.; Wakitani, S.; Nakaya, H.; Tanigami, A.; Seki, T.; Nakamura, Y.; Saito, N.; Sano, K.; Hidaka, E.; Takaoka, K. Use of bone morphogenetic protein 2 and diffusion chambers to engineer cartilage tissue for the repair of defects in articular cartilage. Arthritis Rheum. 2005, 52, 155-163. [CrossRef] [PubMed]

64. Adachi, N.; Sato, K.; Usas, A.; Fu, F.H.; Ochi, M.; Han, C.W.; Niyibizi, C.; Huard, J. Muscle derived, cell based ex vivo gene therapy for treatment of full thickness articular cartilage defects. J. Rheumatol. 2002, 29, 1920-1930. [PubMed]

65. Sakaguchi, Y.; Sekiya, I.; Yagishita, K.; Muneta, T. Comparison of human stem cells derived from various mesenchymal tissues: Superiority of synovium as a cell source. Arthritis Rheum. 2005, 52, 2521-2529. [CrossRef] [PubMed]

66. Park, Y.; Sugimoto, M.; Watrin, A.; Chiquet, M.; Hunziker, E.B. BMP-2 induces the expression of chondrocyte-specific genes in bovine synovium-derived progenitor cells cultured in three-dimensional alginate hydrogel. Osteoarthr. Cartil. 2005, 13, 527-536. [CrossRef] [PubMed]

67. Sampat, S.R.; O'Connell, G.D.; Fong, J.V.; Alegre-Aguarón, E.; Ateshian, G.A.; Hung, C.T. Growth factor priming of synovium-derived stem cells for cartilage tissue engineering. Tissue Eng. Part A 2011, 17, 2259-2265. [CrossRef] [PubMed]

68. Iwasaki, M.; Nakahara, H.; Nakata, K.; Nakase, T.; Kimura, T.; Ono, K. Regulation of proliferation and osteochondrogenic differentiation of periosteum-derived cells by transforming growth factor- $\beta$ and basic fibroblast growth factor. J. Bone Jt. Surg. Am. 1995, 77, 543-554. [CrossRef]

69. You, F.; Wu, X.; Chen, X. 3D Printing of Porous Alginate/gelatin Hydrogel Scaffolds and Their Mechanical Property Characterization. Int. J. Polym. Mater. Polym. Biomater. 2017, 66, 299-306. [CrossRef]

70. Duarte Campos, D.F.; Blaeser, A.; Korsten, A.; Neuss, S.; Jäkel, J.; Vogt, M.; Fischer, H. The stiffness and structure of three-dimensional printed hydrogels direct the differentiation of mesenchymal stromal cells toward adipogenic and osteogenic lineages. Tissue Eng. Part A 2014, 21, 740-756. [CrossRef] [PubMed]

71. Rajaram, A.; Schreyer, D.J.; Chen, D.X. Use of the polycation polyethyleneimine to improve the physical properties of alginate-hyaluronic acid hydrogel during fabrication of tissue repair scaffolds. J. Biomater. Sci. Polym. Ed. 2015, 26, 433-445. [CrossRef] [PubMed]

72. Billiet, T.; Gevaert, E.; De Schryver, T.; Cornelissen, M.; Dubruel, P. The 3D printing of gelatin methacrylamide cell-laden tissue-engineered constructs with high cell viability. Biomaterials 2014, 35, 49-62. [CrossRef] [PubMed]

73. Chameettachal, S.; Midha, S.; Ghosh, S. Regulation of Chondrogenesis and Hypertrophy in Silk Fibroin-Gelatin-Based 3D Bioprinted Constructs. ACS Biomater. Sci. Eng. 2016, 2, 1450-1463. [CrossRef]

74. Smith, C.M.; Stone, A.L.; Parkhill, R.L.; Stewart, R.L.; Simpkins, M.W.; Kachurin, A.M.; Warren, W.L.; Williams, S.K. Three-dimensional bioassembly tool for generating viable tissue-engineered constructs. Tissue Eng. 2004, 10, 1566-1576. [CrossRef] [PubMed]

75. Roach, B.L.; Nover, A.B.; Ateshian, G.A.; Hung, C.T. Agarose Hydrogel Characterization for Regenerative Medicine Applications: Focus on Engineering Cartilage. In Biomaterials from Nature for Advanced Devices and Therapies; John Wiley \& Sons: Hoboken, NJ, USA, 2016; p. 258.

76. Kao, J.M.; Rose, R.; Yousef, M.; Hunter, S.K.; Rodgers, V. In vivo biocompatibility evaluation of Cibacron blue-agarose. J. Biomed. Mater. Res. 1999, 47, 537-542. [CrossRef]

77. Hunt, N.C.; Grover, L.M. Cell encapsulation using biopolymer gels for regenerative medicine. Biotechnol. Lett. 2010, 32, 733-742. [CrossRef] [PubMed]

78. Campos, D.F.D.; Blaeser, A.; Weber, M.; Jäkel, J.; Neuss, S.; Jahnen-Dechent, W.; Fischer, H. Three-dimensional printing of stem cell-laden hydrogels submerged in a hydrophobic high-density fluid. Biofabrication 2012, 5 , 015003. [CrossRef] [PubMed]

79. Augst, A.D.; Kong, H.J.; Mooney, D.J. Alginate hydrogels as biomaterials. Macromol. Biosci. 2006, 6, 623-633. [CrossRef] [PubMed]

80. Wang, Z.; Goh, J.; De, S.D.; Ge, Z.; Ouyang, H.; Chong, J.S.W.; Low, S.L.; Lee, E.H. Efficacy of bone marrow-derived stem cells in strengthening osteoporotic bone in a rabbit model. Tissue Eng. 2006, 12, 1753-1761. [CrossRef] [PubMed] 
81. Diekman, B.O.; Estes, B.T.; Guilak, F. The effects of BMP6 overexpression on adipose stem cell chondrogenesis: Interactions with dexamethasone and exogenous growth factors. J. Biomed. Mater. Res. Part A 2010, 93, 994-1003. [CrossRef] [PubMed]

82. Jia, J.; Richards, D.J.; Pollard, S.; Tan, Y.; Rodriguez, J.; Visconti, R.P.; Trusk, T.C.; Yost, M.J.; Yao, H.; Markwald, R.R. Engineering alginate as bioink for bioprinting. Acta Biomater. 2014, 10, 4323-4331. [CrossRef] [PubMed]

83. Sannino, A.; Demitri, C.; Madaghiele, M. Biodegradable cellulose-based hydrogels: Design and applications. Materials 2009, 2, 353-373. [CrossRef]

84. Thirumala, S.; Gimble, J.M.; Devireddy, R.V. Methylcellulose based thermally reversible hydrogel system for tissue engineering applications. Cells 2013, 2, 460-475. [CrossRef] [PubMed]

85. Vinatier, C.; Magne, D.; Weiss, P.; Trojani, C.; Rochet, N.; Carle, G.; Vignes-Colombeix, C.; Chadjichristos, C.; Galera, P.; Daculsi, G.; et al. A silanized hydroxypropyl methylcellulose hydrogel for the three-dimensional culture of chondrocytes. Biomaterials 2005, 26, 6643-6651. [CrossRef] [PubMed]

86. Berger, J.; Reist, M.; Mayer, J.M.; Felt, O.; Peppas, N.; Gurny, R. Structure and interactions in covalently and ionically crosslinked chitosan hydrogels for biomedical applications. Eur. J. Pharm. Biopharm. 2004, 57, 19-34. [CrossRef]

87. Rinaudo, M. Chitin and chitosan: Properties and applications. Prog. Polym. Sci. 2006, 31, 603-632. [CrossRef]

88. Hong, Y.; Song, H.; Gong, Y.; Mao, Z.; Gao, C.; Shen, J. Covalently crosslinked chitosan hydrogel: Properties of in vitro degradation and chondrocyte encapsulation. Acta Biomater. 2007, 3, 23-31. [CrossRef] [PubMed]

89. Ye, K.; Felimban, R.; Traianedes, K.; Moulton, S.E.; Wallace, G.G.; Chung, J.; Quigley, A.; Choong, P.F.; Myers, D.E. Chondrogenesis of infrapatellar fat pad derived adipose stem cells in 3D printed chitosan scaffold. PLoS ONE 2014, 9, e99410. [CrossRef] [PubMed]

90. Coutinho, D.F.; Sant, S.V.; Shin, H.; Oliveira, J.T.; Gomes, M.E.; Neves, N.M.; Khademhosseini, A.; Reis, R.L. Modified Gellan Gum hydrogels with tunable physical and mechanical properties. Biomaterials 2010, 31, 7494-7502. [CrossRef] [PubMed]

91. Oliveira, J.T.; Gardel, L.S.; Rada, T.; Martins, L.; Gomes, M.E.; Reis, R.L. Injectable gellan gum hydrogels with autologous cells for the treatment of rabbit articular cartilage defects. J. Orthop. Res. 2010, 28, 1193-1199. [CrossRef] [PubMed]

92. Oliveira, J.T.; Martins, L.; Picciochi, R.; Malafaya, P.; Sousa, R.; Neves, N.; Mano, J.F.; Reis, R.L. Gellan gum: A new biomaterial for cartilage tissue engineering applications. J. Biomed. Mater. Res. Part A 2010, 93, 852-863. [CrossRef] [PubMed]

93. Levato, R.; Visser, J.; Planell, J.A.; Engel, E.; Malda, J.; Mateos-Timoneda, M.A. Biofabrication of tissue constructs by 3D bioprinting of cell-laden microcarriers. Biofabrication 2014, 6, 035020. [CrossRef] [PubMed]

94. Mouser, V.H.; Melchels, F.P.; Visser, J.; Dhert, W.J.; Gawlitta, D.; Malda, J. Yield stress determines bioprintability of hydrogels based on gelatin-methacryloyl and gellan gum for cartilage bioprinting. Biofabrication 2016, 8, 035003. [CrossRef] [PubMed]

95. Park, J.Y.; Choi, J.; Shim, J.; Lee, J.; Park, H.; Kim, S.W.; Doh, J.; Cho, D.W. A comparative study on collagen type I and hyaluronic acid dependent cell behavior for osteochondral tissue bioprinting. Biofabrication 2014, 6, 035004. [CrossRef] [PubMed]

96. Jeon, O.; Song, S.J.; Lee, K.; Park, M.H.; Lee, S.; Hahn, S.K.; Kim, S.; Kim, B.S. Mechanical properties and degradation behaviors of hyaluronic acid hydrogels cross-linked at various cross-linking densities. Carbohydr. Polym. 2007, 70, 251-257. [CrossRef]

97. Skardal, A.; Zhang, J.; McCoard, L.; Xu, X.; Oottamasathien, S.; Prestwich, G.D. Photocrosslinkable hyaluronan-gelatin hydrogels for two-step bioprinting. Tissue Eng. Part A 2010, 16, 2675-2685. [CrossRef] [PubMed]

98. Bian, L.; Hou, C.; Tous, E.; Rai, R.; Mauck, R.L.; Burdick, J.A. The influence of hyaluronic acid hydrogel crosslinking density and macromolecular diffusivity on human MSC chondrogenesis and hypertrophy. Biomaterials 2013, 34, 413-421. [CrossRef] [PubMed]

99. Ouyang, L.; Highley, C.B.; Rodell, C.B.; Sun, W.; Burdick, J.A. 3D Printing of shear-thinning hyaluronic acid hydrogels with secondary crosslinking. ACS Biomater. Sci. Eng. 2016, 2, 1743-1751. [CrossRef]

100. Yamamoto, M.; Ikada, Y.; Tabata, Y. Controlled release of growth factors based on biodegradation of gelatin hydrogel. J. Biomater. Sci. Polym. Ed. 2001, 12, 77-88. [CrossRef] [PubMed] 
101. Loessner, D.; Meinert, C.; Kaemmerer, E.; Martine, L.C.; Yue, K.; Levett, P.A.; Klein, T.J.; Melchels, F.P.W.; Khademhosseini, A.; Hutmacher, D.W. Functionalization, preparation and use of cell-laden gelatin methacryloyl-based hydrogels as modular tissue culture platforms. Nat. Protoc. 2016, 11, 727-746. [CrossRef] [PubMed]

102. Tabata, Y.; Ikada, Y. Vascularization effect of basic fibroblast growth factor released from gelatin hydrogels with different biodegradabilities. Biomaterials 1999, 20, 2169-2175. [CrossRef]

103. Das, S.; Pati, F.; Choi, Y.; Rijal, G.; Shim, J.; Kim, S.W.; Ray, A.R.; Cho, D.W.; Ghosh, S. Bioprintable, cell-laden silk fibroin-gelatin hydrogel supporting multilineage differentiation of stem cells for fabrication of three-dimensional tissue constructs. Acta Biomater. 2015, 11, 233-246. [CrossRef] [PubMed]

104. Peng, H.; Poovaiah, N.; Forrester, M.; Cochran, E.; Wang, Q. Ex vivo culture of primary intestinal stem cells in collagen gels and foams. ACS Biomater. Sci. Eng. 2014, 1, 37-42. [CrossRef]

105. Nims, R.J.; Cigan, A.D.; Durney, K.M.; Jones, B.K.; O’Neill, J.D.; Law, W.A.; Vunjak-Novakovic, G.; Hung, C.T.; Ateshian, G.A. Constrained cage culture improves engineered cartilage functional properties by enhancing collagen network stability. Tissue Eng. Part A 2017. [CrossRef] [PubMed]

106. Makris, E.; Hu, J.; Athanasiou, K. Hypoxia-induced collagen crosslinking as a mechanism for enhancing mechanical properties of engineered articular cartilage. Osteoarthr. Cartil. 2013, 21, 634-641. [CrossRef] [PubMed]

107. Rhee, S.; Puetzer, J.L.; Mason, B.N.; Reinhart-King, C.A.; Bonassar, L.J. 3D bioprinting of spatially heterogeneous collagen constructs for cartilage tissue engineering. ACS Biomater. Sci. Eng. 2016, 2, 1800-1805. [CrossRef]

108. Xu, T.; Binder, K.W.; Albanna, M.Z.; Dice, D.; Zhao, W.; Yoo, J.J.; Atala, A. Hybrid printing of mechanically and biologically improved constructs for cartilage tissue engineering applications. Biofabrication 2012, 5 , 015001. [CrossRef] [PubMed]

109. Ahmed, T.A.; Dare, E.V.; Hincke, M. Fibrin: A versatile scaffold for tissue engineering applications. Tissue Eng. Part B 2008, 14, 199-215. [CrossRef] [PubMed]

110. Gao, G.; Cui, X. Three-dimensional bioprinting in tissue engineering and regenerative medicine. Biotechnol. Lett. 2016, 38, 203-211. [CrossRef] [PubMed]

111. Ozbolat, I.T. Bioprinting scale-up tissue and organ constructs for transplantation. Trends Biotechnol. 2015, 33, 395-400. [CrossRef] [PubMed]

112. Lee, Y.; Polio, S.; Lee, W.; Dai, G.; Menon, L.; Carroll, R.S.; Yoo, S.S. Bio-printing of collagen and VEGF-releasing fibrin gel scaffolds for neural stem cell culture. Exp. Neurol. 2010, 223, 645-652. [CrossRef] [PubMed]

113. Novikova, L.N.; Mosahebi, A.; Wiberg, M.; Terenghi, G.; Kellerth, J.; Novikov, L.N. Alginate hydrogel and matrigel as potential cell carriers for neurotransplantation. J. Biomed. Mater. Res. Part A 2006, 77, $242-252$. [CrossRef] [PubMed]

114. Kleinman, H.K.; Martin, G.R. Matrigel: Basement Membrane Matrix with Biological Activity. Seminars in Cancer Biology; Elsevier: Amsterdam, The Netherlands, 2005.

115. Snyder, J.; Hamid, Q.; Wang, C.; Chang, R.; Emami, K.; Wu, H.; Sun, W. Bioprinting cell-laden matrigel for radioprotection study of liver by pro-drug conversion in a dual-tissue microfluidic chip. Biofabrication 2011, 3, 034112. [CrossRef] [PubMed]

116. Fedorovich, N.E.; De Wijn, J.R.; Verbout, A.J.; Alblas, J.; Dhert, W.J. Three-dimensional fiber deposition of cell-laden, viable, patterned constructs for bone tissue printing. Tissue Eng. Part A 2008, 14, 127-133. [CrossRef] [PubMed]

117. Khattak, S.F.; Bhatia, S.R.; Roberts, S.C. Pluronic F127 as a cell encapsulation material: Utilization of membrane-stabilizing agents. Tissue Eng. 2005, 11, 974-983. [CrossRef] [PubMed]

118. Wu, W.; DeConinck, A.; Lewis, J.A. Omnidirectional printing of 3D microvascular networks. Adv. Mater. 2011, 23, H178-H183. [CrossRef] [PubMed]

119. Hwang, N.S.; Varghese, S.; Li, H.; Elisseeff, J. Regulation of osteogenic and chondrogenic differentiation of mesenchymal stem cells in PEG-ECM hydrogels. Cell Tissue Res. 2011, 344, 499-509. [CrossRef] [PubMed]

120. Bryant, S.J.; Bender, R.J.; Durand, K.L.; Anseth, K.S. Encapsulating chondrocytes in degrading PEG hydrogels with high modulus: Engineering gel structural changes to facilitate cartilaginous tissue production. Biotechnol. Bioeng. 2004, 86, 747-755. [CrossRef] [PubMed] 
121. Hockaday, L.; Kang, K.; Colangelo, N.; Cheung, P.; Duan, B.; Malone, E.; Wu, J.; Girardi, L.N.; Bonassar, L.J.; Lipson, H.; et al. Rapid 3D printing of anatomically accurate and mechanically heterogeneous aortic valve hydrogel scaffolds. Biofabrication 2012, 4, 035005. [CrossRef] [PubMed]

122. Williams, D.F. On the mechanisms of biocompatibility. Biomaterials 2008, 29, 2941-2953. [CrossRef] [PubMed]

123. Atala, A.; Yoo, J.J. Essentials of 3D Biofabrication and Translation; Academic Press: Cambridge, MA, USA, 2015.

124. Li, J.; Chen, M.; Fan, X.; Zhou, H. Recent advances in bioprinting techniques: Approaches, applications and future prospects. J. Trans. Med. 2016, 14, 271. [CrossRef] [PubMed]

125. Ballyns, J.J.; Cohen, D.L.; Malone, E.; Maher, S.A.; Potter, H.G.; Wright, T.; Lipson, H.; Bonassar, L.J. An optical method for evaluation of geometric fidelity for anatomically shaped tissue-engineered constructs. Tissue Eng. Part C 2009, 16, 693-703. [CrossRef] [PubMed]

126. Trachtenberg, J.E.; Placone, J.K.; Smith, B.T.; Piard, C.M.; Santoro, M.; Scott, D.W.; Fisher, J.P.; Mikos, A.G. Extrusion-based 3D printing of poly (propylene fumarate) in a full-factorial design. ACS Biomater. Sci. Eng. 2016, 2, 1771-1780. [CrossRef]

127. Nikkhah, M.; Eshak, N.; Zorlutuna, P.; Annabi, N.; Castello, M.; Kim, K.; Dolatshahi-Pirouz, A.; Edalat, F.; Bae, H.; Yang, Y.; et al. Directed endothelial cell morphogenesis in micropatterned gelatin methacrylate hydrogels. Biomaterials 2012, 33, 9009-9018. [CrossRef] [PubMed]

128. You, F.; Wu, X.; Zhu, N.; Lei, M.; Eames, B.F.; Chen, X. 3D Printing of porous cell-laden hydrogel constructs for potential applications in cartilage tissue engineering. ACS Biomater. Sci. Eng. 2016, 2, 1200-1210. [CrossRef]

129. Malda, J.; Visser, J.; Melchels, F.P.; Jüngst, T.; Hennink, W.E.; Dhert, W.J.; Groll, J.; Hutmacher, D.W. 25th anniversary article: Engineering hydrogels for biofabrication. Adv. Mater. 2013, 25, 5011-5028. [CrossRef] [PubMed]

130. Li, M.; Tian, X.; Schreyer, D.J.; Chen, X. Effect of needle geometry on flow rate and cell damage in the dispensing-based biofabrication process. Biotechnol. Prog. 2011, 27, 1777-1784. [CrossRef] [PubMed]

131. Guvendiren, M.; Lu, H.D.; Burdick, J.A. Shear-thinning hydrogels for biomedical applications. Soft Matter 2012, 8, 260-272. [CrossRef]

132. Nichol, J.W.; Koshy, S.T.; Bae, H.; Hwang, C.M.; Yamanlar, S.; Khademhosseini, A. Cell-laden microengineered gelatin methacrylate hydrogels. Biomaterials 2010, 31, 5536-5544. [CrossRef] [PubMed]

133. Phelps, E.A.; Enemchukwu, N.O.; Fiore, V.F.; Sy, J.C.; Murthy, N.; Sulchek, T.A.; Barker, T.H.; García, A.J. Maleimide cross-linked bioactive peg hydrogel exhibits improved reaction kinetics and cross-linking for cell encapsulation and in situ delivery. Adv. Mater. 2012, 24, 64-70. [CrossRef] [PubMed]

134. Izadifar, Z.; Chen, X.; Kulyk, W. Strategic design and fabrication of engineered scaffolds for articular cartilage repair. J. Funct. Biomater. 2012, 3, 799-838. [CrossRef] [PubMed]

135. Zhang, L.; Rodriguez, J.; Raez, J.; Myles, A.J.; Fenniri, H.; Webster, T.J. Biologically inspired rosette nanotubes and nanocrystalline hydroxyapatite hydrogel nanocomposites as improved bone substitutes. Nanotechnology 2009, 20, 175101. [CrossRef] [PubMed]

136. Chang, C.; Peng, N.; He, M.; Teramoto, Y.; Nishio, Y.; Zhang, L. Fabrication and properties of chitin/hydroxyapatite hybrid hydrogels as scaffold nano-materials. Carbohydr. Polym. 2013, 91, 7-13. [CrossRef] [PubMed]

137. Khanarian, N.T.; Jiang, J.; Wan, L.Q.; Mow, V.C.; Lu, H.H. A hydrogel-mineral composite scaffold for osteochondral interface tissue engineering. Tissue Eng. Part A 2011, 18, 533-545. [CrossRef] [PubMed]

138. Lee, C.H.; Cook, J.L.; Mendelson, A.; Moioli, E.K.; Yao, H.; Mao, J.J. Regeneration of the articular surface of the rabbit synovial joint by cell homing: A proof of concept study. Lancet 2010, 376, 440-448. [CrossRef]

139. Visser, J.; Melchels, F.P.; Jeon, J.E.; van Bussel, E.M.; Kimpton, L.S.; Byrne, H.M.; Dhert, W.J.; Dalton, P.D.; Hutmacher, D.W.; Malda, J. Reinforcement of hydrogels using three-dimensionally printed microfibres. Nat. Commun. 2015, 6. [CrossRef] [PubMed]

140. Tabriz, A.G.; Hermida, M.A.; Leslie, N.R.; Shu, W. Three-dimensional bioprinting of complex cell laden alginate hydrogel structures. Biofabrication 2015, 7, 045012. [CrossRef] [PubMed]

141. Schuurman, W.; Khristov, V.; Pot, M.; Van Weeren, P.; Dhert, W.; Malda, J. Bioprinting of hybrid tissue constructs with tailorable mechanical properties. Biofabrication 2011, 3, 021001. [CrossRef] [PubMed]

142. Olubamiji, A.D.; Izadifar, Z.; Si, J.L.; Cooper, D.M.; Eames, B.F.; Chen, D.X. Modulating mechanical behaviour of 3D-printed cartilage-mimetic PCL scaffolds: Influence of molecular weight and pore geometry. Biofabrication 2016, 8, 025020. [CrossRef] [PubMed] 
143. Pati, F.; Jang, J.; Ha, D.; Kim, S.W.; Rhie, J.; Shim, J.; Kim, D.H.; Cho, D.W. Printing three-dimensional tissue analogues with decellularized extracellular matrix bioink. Nat. Commun. 2014, 5. [CrossRef] [PubMed]

144. Klein, T.J.; Rizzi, S.C.; Reichert, J.C.; Georgi, N.; Malda, J.; Schuurman, W.; Crawford, R.W.; Hutmacher, D.W. Strategies for zonal cartilage repair using hydrogels. Macromol. Biosci. 2009, 9, 1049-1058. [CrossRef] [PubMed]

145. Khalil, S.; Sun, W. Bioprinting endothelial cells with alginate for 3D tissue constructs. J. Biomech. Eng. 2009, 131, 111002. [CrossRef] [PubMed]

146. Arlov, Ø.; Aachmann, F.L.; Sundan, A.; Espevik, T.; Skjak-Bræk, G. Heparin-like properties of sulfated alginates with defined sequences and sulfation degrees. Biomacromolecules 2014, 15, 2744-2750. [CrossRef] [PubMed]

147. Freeman, I.; Kedem, A.; Cohen, S. The effect of sulfation of alginate hydrogels on the specific binding and controlled release of heparin-binding proteins. Biomaterials 2008, 29, 3260-3268. [CrossRef] [PubMed]

148. Müller, M.; Öztürk, E.; Arlov, Ø.; Gatenholm, P.; Zenobi-Wong, M. Alginate Sulfate-Nanocellulose Bioinks for Cartilage Bioprinting Applications. Ann. Biomed. Eng. 2016, 45, 210-223. [CrossRef] [PubMed]

149. Öztürk, E.; Arlov, Ø.; Aksel, S.; Li, L.; Ornitz, D.M.; Skjåk-Bræk, G.; Wong, Z.M. Sulfated hydrogel matrices direct mitogenicity and maintenance of chondrocyte phenotype through activation of fgf signaling. Adv. Funct. Mater. 2016, 26, 3649-3662. [CrossRef]

150. Prestwich, G.D. Hyaluronic acid-based clinical biomaterials derived for cell and molecule delivery in regenerative medicine. J. Controll. Release 2011, 155, 193-199. [CrossRef] [PubMed]

151. Burdick, J.A.; Prestwich, G.D. Hyaluronic acid hydrogels for biomedical applications. Adv. Mater. 2011, 23, H41-H56. [CrossRef] [PubMed]

152. Müller, M.; Becher, J.; Schnabelrauch, M.; Zenobi-Wong, M. Nanostructured Pluronic hydrogels as bioinks for 3D bioprinting. Biofabrication 2015, 7, 035006. [CrossRef] [PubMed]

153. Pescosolido, L.; Schuurman, W.; Malda, J.; Matricardi, P.; Alhaique, F.; Coviello, T.; van Weeren, P.R.; Dhert, W.J.; Hennink, W.E.; Vermonden, T. Hyaluronic acid and dextran-based semi-IPN hydrogels as biomaterials for bioprinting. Biomacromolecules 2011, 12, 1831-1838. [CrossRef] [PubMed]

154. Wang, X.; Mäkitie, A.A.; Partanen, J.; Tuomi, J.; Paloheimo, K.; Yliperttula, M. The Integrations of Biomaterials and Rapid Prototyping Techniques for Intelligent Manufacturing of Complex Organs; InTechOpen: Rijeka, Croatia, 2013.

155. Ifkovits, J.L.; Burdick, J.A. Review: Photopolymerizable and degradable biomaterials for tissue engineering applications. Tissue Eng. 2007, 13, 2369-2385. [CrossRef] [PubMed]

156. Cohen, D.L.; Lipton, J.I.; Bonassar, L.J.; Lipson, H. Additive manufacturing for in situ repair of osteochondral defects. Biofabrication 2010, 2, 035004. [CrossRef] [PubMed]

157. Fedorovich, N.E.; Schuurman, W.; Wijnberg, H.M.; Prins, H.; van Weeren, P.R.; Malda, J.; Alblas, J.; Dhert, W.J. Biofabrication of osteochondral tissue equivalents by printing topologically defined, cell-laden hydrogel scaffolds. Tissue Eng. Part C 2011, 18, 33-44. [CrossRef] [PubMed]

158. Abbadessa, A.; Blokzijl, M.; Mouser, V.; Marica, P.; Malda, J.; Hennink, W.; Vermonden, T. A thermo-responsive and photo-polymerizable chondroitin sulfate-based hydrogel for 3D printing applications. Carbohydr. Polym. 2016, 149, 163-174. [CrossRef] [PubMed]

159. Melchels, F.P.; Dhert, W.J.; Hutmacher, D.W.; Malda, J. Development and characterisation of a new bioink for additive tissue manufacturing. J. Mater. Chem. B 2014, 2, 2282-2289. [CrossRef]

160. Izadifar, Z.; Chang, T.; Kulyk, W.; Chen, X.; Eames, B.F. Analyzing biological performance of 3D-printed, cell-impregnated hybrid constructs for cartilage tissue engineering. Tissue Eng. Part C 2016, 22, 173-188. [CrossRef] [PubMed]

161. Shim, J.; Lee, J.; Kim, J.Y.; Cho, D. Bioprinting of a mechanically enhanced three-dimensional dual cell-laden construct for osteochondral tissue engineering using a multi-head tissue/organ building system. J. Micromech. Microeng. 2012, 22, 085014. [CrossRef]

162. Shim, J.; Jang, K.; Hahn, S.K.; Park, J.Y.; Jung, H.; Oh, K.; Park, K.M.; Yeom, J.; Park, S.H.; Kim, S.W.; et al. Three-dimensional bioprinting of multilayered constructs containing human mesenchymal stromal cells for osteochondral tissue regeneration in the rabbit knee joint. Biofabrication 2016, 8, 014102. [CrossRef] [PubMed]

163. Deng, D.; Liu, W.; Cheema, U.; Mudera, V.; Hadjipanayi, E.; Brown, R.A. Less is more: New biomimetic approach to control spatial and temporal cell loading for tissue engineering. J. Biomed. Mater. Res. Part A 2014, 102, 4108-4117. [CrossRef] [PubMed]

164. Kim, Y.; Sah, R.L.; Grodzinsky, A.J.; Plaas, A.H.; Sandy, J.D. Mechanical regulation of cartilage biosynthetic behavior: Physical stimuli. Arch. Biochem. Biophys. 1994, 311, 1-12. [CrossRef] [PubMed] 
165. Grodzinsky, A.J.; Levenston, M.E.; Jin, M.; Frank, E.H. Cartilage tissue remodeling in response to mechanical forces. Annu. Rev. Biomed. Eng. 2000, 2, 691-713. [CrossRef] [PubMed]

166. Kim, T.; Sharma, B.; Williams, C.; Ruffner, M.; Malik, A.; McFarland, E.; Elisseeff, J.H. Experimental model for cartilage tissue engineering to regenerate the zonal organization of articular cartilage. Osteoarthr. Cartil. 2003, 11, 653-664. [CrossRef]

167. Sharma, B.; Williams, C.G.; Kim, T.K.; Sun, D.; Malik, A.; Khan, M.; Leong, K.; Elisseeff, J.H. Designing zonal organization into tissue-engineered cartilage. Tissue Eng. 2007, 13, 405-414. [CrossRef] [PubMed]

168. Coates, E.E.; Riggin, C.N.; Fisher, J.P. Matrix molecule influence on chondrocyte phenotype and proteoglycan 4 expression by alginate-embedded zonal chondrocytes and mesenchymal stem cells. J. Orthop. Res. 2012, 30, 1886-1897. [CrossRef] [PubMed]

169. Nguyen, L.H.; Kudva, A.K.; Guckert, N.L.; Linse, K.D.; Roy, K. Unique biomaterial compositions direct bone marrow stem cells into specific chondrocytic phenotypes corresponding to the various zones of articular cartilage. Biomaterials 2011, 32, 1327-1338. [CrossRef] [PubMed]

170. Nguyen, L.H.; Kudva, A.K.; Saxena, N.S.; Roy, K. Engineering articular cartilage with spatially-varying matrix composition and mechanical properties from a single stem cell population using a multi-layered hydrogel. Biomaterials 2011, 32, 6946-6952. [CrossRef] [PubMed]

171. Wise, J.K.; Yarin, A.L.; Megaridis, C.M.; Cho, M. Chondrogenic differentiation of human mesenchymal stem cells on oriented nanofibrous scaffolds: Engineering the superficial zone of articular cartilage. Tissue Eng. Part A 2008, 15, 913-921. [CrossRef] [PubMed]

172. Chhaya, M.P.; Poh, P.S.; Balmayor, E.R.; van Griensven, M.; Schantz, J.; Hutmacher, D.W. Additive manufacturing in biomedical sciences and the need for definitions and norms. Expert Rev. Med. Devices 2015, 12, 537-543. [CrossRef] [PubMed]

173. Chen, X. Dispensed-Based Bio-Manufacturing Scaffolds for Tissue Engineering Applications. Int. J. Eng. Appl. 2014, 2, 10-19.

174. Li, M.; Tian, X.; Zhu, N.; Schreyer, D.J.; Chen, X. Modeling process-induced cell damage in the biodispensing process. Tissue Eng. Part C 2009, 16, 533-542. [CrossRef] [PubMed]

175. Yu, Y.; Zhang, Y.; Martin, J.A.; Ozbolat, I.T. Evaluation of cell viability and functionality in vessel-like bioprintable cell-laden tubular channels. J. Biomech. Eng. 2013, 135, 091011. [CrossRef] [PubMed]

176. Sarker, M.; Chen, X. Modeling the Flow Behavior and Flow Rate of Medium Viscosity Alginate for Scaffold Fabrication with a Three-Dimensional Bioplotter. J. Manuf. Sci. Eng. 2017, 139, 081002. [CrossRef]

177. Chen, X. Modeling and control of fluid dispensing processes: A state-of-the-art review. Int. J. Adv. Manuf. Technol. 2009, 43, 276-286. [CrossRef]

178. Chen, X.; Li, M.; Ke, H. Modeling of the flow rate in the dispensing-based process for fabricating tissue scaffolds. J. Manuf. Sci. Eng. 2008, 130, 021003. [CrossRef]

179. Adamkiewicz, M.; Rubinsky, B. Cryogenic 3D printing for tissue engineering. Cryobiology 2015, 71, 518-521. [CrossRef] [PubMed]

180. Cohen, D.L.; Lo, W.; Tsavaris, A.; Peng, D.; Lipson, H.; Bonassar, L.J. Increased mixing improves hydrogel homogeneity and quality of three-dimensional printed constructs. Tissue Eng. Part C 2010, 17, 239-248. [CrossRef] [PubMed]

181. Ning, L.; Xu, Y.; Chen, X.; Schreyer, D.J. Influence of mechanical properties of alginate-based substrates on the performance of Schwann cells in culture. J. Biomater. Sci. Polym. Ed. 2016, 27, 898-915. [CrossRef] [PubMed]

182. Cao, N.; Chen, X.; Schreyer, D. Influence of calcium ions on cell survival and proliferation in the context of an alginate hydrogel. ISRN Chem. Eng. 2012, 2012, 1-9. [CrossRef]

183. He, Y.; Yang, F.; Zhao, H.; Gao, Q.; Xia, B.; Fu, J. Research on the printability of hydrogels in 3D bioprinting. Sci. Rep. 2016, 6, 29977. [CrossRef] [PubMed]

184. Little, C.J.; Bawolin, N.K.; Chen, X. Mechanical properties of natural cartilage and tissue-engineered constructs. Tissue Eng. Part B 2011, 17, 213-227. [CrossRef] [PubMed]

185. Huang, B.J.; Hu, J.C.; Athanasiou, K.A. Cell-based tissue engineering strategies used in the clinical repair of articular cartilage. Biomaterials 2016, 98, 1-22. [CrossRef] [PubMed]

(C) 2017 by the authors. Licensee MDPI, Basel, Switzerland. This article is an open access article distributed under the terms and conditions of the Creative Commons Attribution (CC BY) license (http:/ / creativecommons.org/licenses/by/4.0/). 